\title{
Plastic Surgery Update on the Biology of Fat Cells and Adipose-Derived Stem Cells for Fat Grafting
}

\author{
Gordon H. Sasaki \\ Medical University Center, Private Practice, Pasadena, CA, USA \\ Email: ghsasakimd@drsasaki.com
}

Received 17 May 2015; accepted 3 June 2015; published 10 June 2015

Copyright (C) 2015 by author and OALib.

This work is licensed under the Creative Commons Attribution International License (CC BY). http://creativecommons.org/licenses/by/4.0/

C. (i) Open Access

\section{Abstract}

The cell biology of adipocytes has led to a number of promising concepts in the last century, especially in the areas of obesity and associated diseases, lipid homeostasis and endocrine functions. Recent advances in adipogenesis had provided insights into understanding of the complex cues for influencing the cytoarchitecture, epigenomic remodeling, signaling pathways and transcription regulators on gene actions for both white and brown adipogenic progression from mesenchymal stem cells to matured committed adipocytes. The recent isolation of preadipocyte populations in vivo and their identification by specific markers may become crucial for manipulating these populations as they become potential targets of novel therapeutics in treating condition of metabolic dysfunctions such as obesity. Cell-biology-related research on preadipocyte (adiposal-mesenchymal cell) differentiation laid the foundation for discoveries of adipose-derived cells (both in stromal vascular fraction, or SVF, and adipose-derived stromal/stem cells, or ASCs), which had become an increasing interest to both stem cell biologists and clinicians because of their potential for angiogenesis and suppression of inflammation for tissue engineering and treatments. The burgeoning preclinical and clinical experience with human adult adipose-derived cells appears to be promising but interpretation of the current literature with in vitro studies, translational research and FDA-registered investigations emphasizes the need for standardized methods to advance basic science knowledge and beneficial safe clinical outcomes. Since the specialty of Plastic Surgery with its position statement on stem cells and fat grafting is committed to advancing evidencebase preclinical and clinical studies in compliance with FDA-regulations, an updated review of cell biology provides insights to achieve these goals.

\section{Keywords}

Fat Biology, Signal Transduction, Preadipocytes, Adipocyte-Derived Cells, Stromal Vascular Fraction, Adipose Stem Cells, Tissue Engineering 


\section{Introduction}

For over 120 years, plastic surgeons have recognized the potential value of autologous fat as an abundant, ideal and practical replacement tissue for point-of-care correction of reconstructive and aesthetic purposes. Ensuing specialists later determined that this multifunctional organ contained a number of valuable resident cells, other worthy non-indigenous cellular populations and a quantity of distinct structural elements, which possessed the potential to optimize fat graft survival and eventually further tissue engineering applications in regenerative medicine. In 1893, Neuber first reported the use of excised fat grafts to correct depressed scars of the face and upper arm that unfortunately concluded with complications and unacceptable aesthetic results [1]. Since then, thousands of experimental investigations, preclinical analyses, clinical studies and anecdotal observations have modified grafting methods to improve fat retention [2]-[4]. For example, the introduction of liposuction and tumescent anesthesia fundamentally changed procurement to one of obtaining free smaller fat lobules for both smaller and larger volume cases in a safer, more efficient manner with lower patient morbidity than experienced by excisional methods [5]-[7]. Furthermore, the technical components of liposuction enabled practitioners to investigate methodically its impact on improving fat harvesting, and by extension, the subsequent steps of processing, transferring, and preparing the recipient site as components of the entire grafting procedure.

Despite significant technical improvements and initial successes over the past two decades, plastic surgeons still remained perplexed by inconsistent and unpredictable retention rates of $25 \%$ - $90 \%$ in different and even same patients [8]. Clearly, there was a progressive loss of the transplanted mature adipocytes along with a conversion of a portion of the graft to fibrous scar tissue, both of which contributed to the final soft tissue volume [9] [10]. The underlying and yet undefined mechanisms of tissue loss after lipo-grafting during the critical period of fat cell survival were thought to be primarily from insufficient vascularity, in addition to mechanical disruption of cells, chemical-environmental insults, and apoptosis, leading to eventual cell death [2] [3] [11]. Since Coleman formalized steps to avoid these deleterious factors in his "lipostructure technique", the use of his recommendations resulted in more consistent, but still variable outcomes [12]. The accumulated data from numerous investigations continued to present a conflicting body of evidence on the impact steps of the grafting procedure on fat survival outcomes because of the use of different protocols, limited control of significant variables, absence of standardized volumetric assessment of graft retention, publication of low-powered studies, and presence of short-termed follow ups. In addition, experienced surgeons found the advocated protocols of different studies and their resultant data within an individual publication difficult to compare, interpret, and implement within their practices. To compensate for these disappointing and capricious results in both small- and large-volume cases, surgeons felt more secure by filling beyond graft-to-capacity ratios and practicing serial grafting, while acknowledging that the composition of the non-aqueous constituents of the fat grafts had remained essentially the same. Because of the rapidly evolving nature of fat grafting in the past decade, this manuscript was written to provide an update of current literature by systematically examining modern concepts of fat biology in order to assess their limitations and value on graft survival and clinical outcomes as well as their potential applications in regenerative medicine for plastic surgery. Current basic science knowledge of adipose-derived cells (both stromal vascular fraction, or SVF, and adipose-derived stromal/stem cells, or ASCs) are of significance for reconstructive an aesthetic purposes. Although practicing clinicians do not need to understand the details of adipose-derived cells in detail, basic science knowledge is the foundation upon which the safety and efficacy of our present and future treatments are based.

\section{Modern Concepts of Mesenchymal Stem Cells}

Since Ernst Haeckel first applied the term, "Stammzelle" (German for stem cell), in 1868 to describe the unicellular ancestor of all multicellular organisms [13], the transformational pathway from embryonal to adult cells was not clarified in modern terms until the early 1900s when the earliest totipotential stem cells in ontogeny were identified in the morula stages of zygotic development [14]. In the 1960s, confirming landmark studies [15]-[17] in adult mouse marrow provided direct in vitro evidence of common putative progenitor stem cells that transitioned from pluripotential cells along a more committed path to differentiated hematopoietic stem cells 
(HSCs) with their presence substantiated in later animal studies by self-renewal and multi-lineage differentiation criteria [14]. In 1968, Friedenstein and colleagues [18] first reported that a small number of adherent spindle-shaped non-hematopoietic mesenchymal cells from adult rat bone marrow were capable of differentiating into deposits of bone or cartilage in vitro, and later confirmed their presence in transplanted animal studies [19]-[21]. Although these early pivotal experiments investigated mesenchymal stem cells (MSCs) exclusively from bone marrow tissue, analogous mesenchymal progenitors have been since found in almost every post-natal organ and tissue in adult mice [22]. In like fashion, human multipotent mesenchymal stromal cells were first detected in marrow stroma (BM-hMSCs), later induced in culture to differentiate exclusively into adipocytic, chondrocytic or osteocytic mesenchymal lineages [23] [24], and controversially, also into non-mesodermal cells such as hepatocytes and neural cells [25]-[27], and ultimately established in transplantation immuno-deficient mice studies [28]. Later, hMSCs, with similar characteristics to BM-hMSCs, were isolated in vitro from human synovial membrane [29], deciduous teeth [30], skin [31], periodontal ligament [32], trabecular bone [33], umbilical cord [34] [35], periosteum [36], and pericytes [37].

Since Owen [38] and Caplan [39] introduced, respectively, the terms stromal stem cell or mesenchymal stem cells (MSCs) to the scientific literature over twenty-five years ago, MSCs have established themselves with current in vitro credentials as rare and independent populations in their niches within fully specialized adult tissues [37] [40] [41]. Originally these cells were designated as mesenchymal stem cells of mesodermal lineage because of their in vitro capacity to differentiate into osteoblasts, chondroblasts and adipocytes, but were often discovered to lack the stem cell traits of self-renewal or multipotent differentiation in vivo. Moreover, the standard isolation procedures for hMSCs, based on plastic adherence to culture plates, resulted in heterogenous cultures of subsets of stem cells and more differentiated progenitor cells. Characterization of MSCs today involves a combination of culture properties, phenotypic marker expression, multi-lineage differentiation capacity and identification of tissue of origin. Despite years of extensive research, no markers have been identified to date that specifically identity native MSCs, their locations and roles within their tissues of origin [37] [40], even though a number of candidates have been proposed [42] [43]. Moreover, MSCs have been known to undergo not only phenotypic changes, but also acquisition of new markers and shedding of original ones during ex vivo cell culturing [44]. To add to the confusion, MSCs have demonstrated levels of plasticity in vitro by transdifferentiating across mesenchymal cell lineages of mature cells from adipocytes or chondrocytes to osteoblasts [45]-[47]. To address such discrepancies between nomenclature and biologic traits of these heterogenous populations, the International Society of Cellular Therapy (ISCT) in 2006 attempted to clarify the definition of these plastic-adherent cells, regardless of the tissues from which they were isolated, by designating them "multipotent mesenchymal stromal cells", while reserving the term "mesenchymal stem cells" only for the subset(s) that met specified stem cell criteria. Although these criteria represented helpful attempts to standardized cell preparations for clinical research, the characterization of MSCs remained elusive due to the lack of unique and definitive cellular markers. Nevertheless, the ISCT released two position papers that stated four minimal criteria [48] [49] that defined cultured MSC populations.

I. The MSCs must exhibit adherence to plastic in standard culture conditions using tissue culture flasks.

II. Greater than 95\% of MSC population must express lineage markers CD105, CD73, and CD90 by flow cytometry.

III. Less than 2\% of MSC population can express of hematopoietic lineage markers CD45, CD34, CD14 or CD11b, CD79 $\alpha$ or CD19 and HLA class II.

IV. The MSC population must demonstrate in vitro differentiation into osteoblasts, adipocytes, and chondrocytes by staining in cell cultures.

In general, hMSCs were quiescent under normal conditions in vivo and were able to respond to tissue injury by proliferating lineage-committed progenitors into terminally differentiated cells. Although hMSCs exhibited in vitro intense paracrine activity by secreting a number of bioactive molecules with trophic [50] [51], angiogenetic [52], immunomodulatory [53] and immunosuppressive [54]-[56] capacities, there was considerable deliberation about their pivotal in vivo roles, contributions, and mechanisms in restoring damaged or aging tissues. As of June 2, 2012, there were over 220 open hMSCs clinical trials registered at clinicaltrials.gov to treat graft-versus-host diseases [57]-[59], autoimmune disorders [60]-[63], bone and cartilage repair [64] [65], cardiac [66]-[68], neurological [69] [70] and renal [71] diseases. Although the mesenchymal stromal cell populations derived from these sources were promising, common problems that continued to hinder their clinical usage included low number of harvested cells based on specific markers, limited amount of harvested tissue, necessitat- 
ing ex vivo expansion, and finally, safety requirements [72]-[74].

\section{Adipogenic Lineage}

\subsection{Adipose-MSCs}

A long-standing paradigm in human adipose tissue biology was that all adipocytes originated in the embryonic mesodermal germ layer from pleuripotential MSCs and developed throughout intrauterine and adult life [75] [76]. As previously mentioned, MSCs can be stimulated to differentiate also into other mesodermal phenotypes (osteoblasts, chondrocytes and myoblasts). Resident adipocyte progenitor cells (adipose MSCs) were thought to be detected as early as the sixth week of gestation in human embryos by immunohistochemical and ultrastructural evidence of cytoplasmic lipid droplets and formation of the basal laminar in these cells [77]. These adiposal mesenchymal-derived stem cells were believed to be localized within emerging vascular networks, where regional fat depots would eventually arise and develop as vascular-adipose niches for resident self-renewing populations of adipocyte progenitors. Although light and electron microscopy studies [78]-[82] over the past 40 years suggested a close time-space interdependency between adipocyte progenitor cells to adipose tissue vasculature, it remained to be proven whether the resident adipocyte cell lineage started off with MSCs or vascular stem cells (VSCs) of endothelial, mural, pericytal, adventitial or stromal populations. A significant barrier to identifying and isolating adipocyte progenitor cell populations, capable of differentiating into functional mature adipocytes in vitro and in vivo, has been the use of surface markers and gene expression programs of primary committed preadipocytes in a heterogeneous cell population within the vascular stromal tissue [83]-[86]. Some markers were not individually specific for the adipose lineage, while others were functionally dispensible for the initial formation of adipocyte progenitor cells. Surface markers often did not provide information for locating adipose precursors in vivo.

Recent investigations, however, strongly suggested a "birth-source" for the adipose stem lineage in perivascular niches within the stromal vascular fraction of adipose tissue. Graff and colleagues [87] identified and localized a subset of adipose-resident progenitors within the mural cell compartment of vessels in the adipose stromal vascular fraction, but not within the vasculature of other tissues in "knock-in" mice, that expressed peroxisome proliferator-activated receptor gamma (PPAR $\gamma$ ), a central regulator of differentiation during adipogenesis, and also an adipocyte GFP expression. The PPAR $\gamma$-GFP cells expressed additionally the mural-endothelial cell markers PDGFR $\beta$, SM-actin and NG2, suggesting that these cells were related to mesoangioblasts, a population of mesenchymal-like stem cells derived from pericytes within the vessel walls [88]. Other investigations have added validation to these initial observations and demonstrated a number of supportive findings such as 1) preadipocytes, endothelial cells and pericytes shared common surface antigens [87] [89]; 2) perivascular cells, [90]-[95], especially pericytes [89] [96]-[99] and adventitial cells [100]-[103], that were isolated from adipose tissue, were believed to behave as vascular stem cells (VCSs), capable of differentiating into adipocytes, osteocytes and chondrocytes; 3) endothelial cells, that were converted into mesenchymal stem cells, differentiated into adipocytes, chondrocytes and osteoblasts [104]; 4) Zfp423, a multi-zinc finger transcriptional regulator of preadipocyte commitment was discovered in a small subset of capillary endothelial cells within white adipose (WAT) and brown adipose (BAT) tissues, but not in endothelial cells of other examined embryonic tissues [105]; 5) the presence of VE-cadherin promotor, a specific marker and requirement for formation of vasculature, was expressed specifically in both progenitor endothelial-pericytes and adipocyte stem cells in human white adipose tissue (WAT) and brown adipose tissue (BAT) [106]; 6) human adipocytes have been observed to have the potential to rapidly acquire an endothelial phenotype in vitro [107]; and 7) adipose progenitor cells were observed to differentiate into endothelial cells and induced angiogenesis within adipose tissue [108] [109]. The cumulative data suggested a complex relationship amongst resident cells in the vasculo-adipocytic niches that involve MCS/VSC progenitors, leading to significant adipogenesis along preadipocytic lineage development. The interface of adipocyte progenitor cells and endothelial cells was suggested to induce a stable, functional and robust vascular network in vivo by direct cell-cell interactions or through paracrine signaling [98] [110] [111]. Data also supported the possibility that adipocytes and endothelial cells postnatally retained sufficient plasticity to undergo transformations between themselves in order to maintain homeostatic balance during adipose tissue expansion and reduction.

Although the previously presented data was compelling for resident adipocyte progenitors or mesenchymal cells to originate from within an adipose-vascular niche [84] [87], other tissues throughout the body were also 
observed to contain progenitor cells capable of adipogenic differentiation. For example, bone marrow represented a rich source for both mesenchymal and hematopoietic (myeloid) stem cells. Although bone marrow mesenchymal cells (BM-MSCs) were not believed to enter the systemic circulation, BM-myeloid (hematopoietic) cells with mesenchymal characteristics have been found to leave the marrow as possible adipocyte progenitor cells in the form of "colony-forming-unit fibroblasts", distribute throughout the circulation, and enter the slow, rate-limiting step of extravasation across the endothelium and differentiate into mature adipocytes within extramedullary adipose depots [112]-[117]. There was also evidence that a subset of adipocytes was derived from the neural crest of the neurectoderm, capable of developing in vitro and in vivo facial adipocytes in the mice model [118]-[120]. The precise roles and contributions of these non-resident progenitor cells, capable of developing into adipose tissue, will require further investigation.

\subsection{Preadipocytic Progression}

Although there have been significant advances in defining adipocyte development in vitro, the early molecular events that promoted MSCs to commit to progenitors of adipocytic lineage, and ultimately to differentiate into mature adipocytes have yet to be fully elucidated [121]. Current investigations [122] [123] have begun to shed light on salient primary events that enable multipotent MSCs to enter the first phase, called determination, that involves commitment to the adipocyte lineage into preadipocytes. Preadipocytes, morphologically indistinguishable from its precursor cell, have lost their potential to differentiate into other cell types. The committed preadipocyte population is stimulated then to proliferate to confluence, resulting in growth arrest during a transition phase, followed by subsequent mitotic clonal expansion, and finally terminal adipocytic differentiation of a mature adipocyte. For efficient and responsive adipogenesis, however, an increasingly complex signaling network, as described below, is required to regulate at several levels and is mediated by a variety of interactive contributions from the neurohormonal axis, specific extra- and intracellular structural remodeling factors, epigenomic (e.g., methylation or histone modification of deoxyribonucleic acid) modifiers, intermediate signaling ligand-receptor pathways and downstream transcription regulators. The net effect is highly dependent on spatiotemporal expression of these components to meet cellular and tissue needs, highlighting the complexity of the differentiating in vitro responses. Many of these ligands are found in the circulation from cell secretions, while others are released within the adipogenic committed cells. The balancing of these poorly understood integrated factors determines the developmental pathway, oftentimes concomitantly promoting an individual track, while discouraging another path by switching genes off or on for adipose tissue requirements.

Early investigations [124] [125] on adipogenesis suggested that pro-adipogenic factors signaled non-contacted, spindly-shaped MSCs in culture to promote an elastic, less tense/stiff extracellular matrix (ECM) that facilitated a more confluent proliferative growth-pattern promoting the development of intracellular structural changes and inducing the formation of spherical-shaped cells in preparation for adipogenesis. Conversely, a stiff and tensioned ECM by fibronectin, for example, had been shown to impede the transformation of spindly-shaped 3T30F442A MSCs to spherical-shaped adipocytes [126], and thus committing them towards osteogenesis at the expense of adipogenesis [127] [128].

Recent bio-molecular data have begun to examine potential collaborative roles for members of the matrix metalloproteinase (MMP) family [129], signaling ligand-receptors of the canonical or non-canonical WNT family [130], the RHO-family GTPase [131], and the TGF $\beta$ super family [132] which includes the BMP family [133] [134] either to promote or inhibit adipose lineage commitment (Figure 1). For instance, proliferative MSCs in vitro are capable of secreting one of the members of the MMP family, whose peptidase activity can lessen the stiffness and alter the composition of their micro-environment to promote spherical cellular changes that initiate proadipogenic lineage development [135]. On the other hand, secretion of tissue inhibitor MMPs (TIMPs) has been found to terminate the differentiation of committed preadipocytes and reduce in vivo adipose tissue development [136] [134]. Moreover, MSCs subjected to mechanical in vitro stress were found to be unable to undergo differentiation to preadipoctyes because of activation of the inhibitory canonical WNT signaling pathway following binding of the glycoprotein, WNT10B ligand to cell surface receptors LRP5, LRP6 and Frizzled [138] [139]. The activated receptors translocated a cytoplasmic $\beta$-catenin molecule into the nucleus [140] where it recruited a co-activator complex to transcription factors [141], peroxisome proliferator-activated receptor $\gamma$ $(\mathrm{PPAR} \gamma)$ and CCAAT/enhancer-binding protein (C/EBP) targeting genes [142] that either inhibited white adipogenesis or promoted osteogenesis and brown adipogenesis [143] [144]. Through a non-canonical WNT5B li 


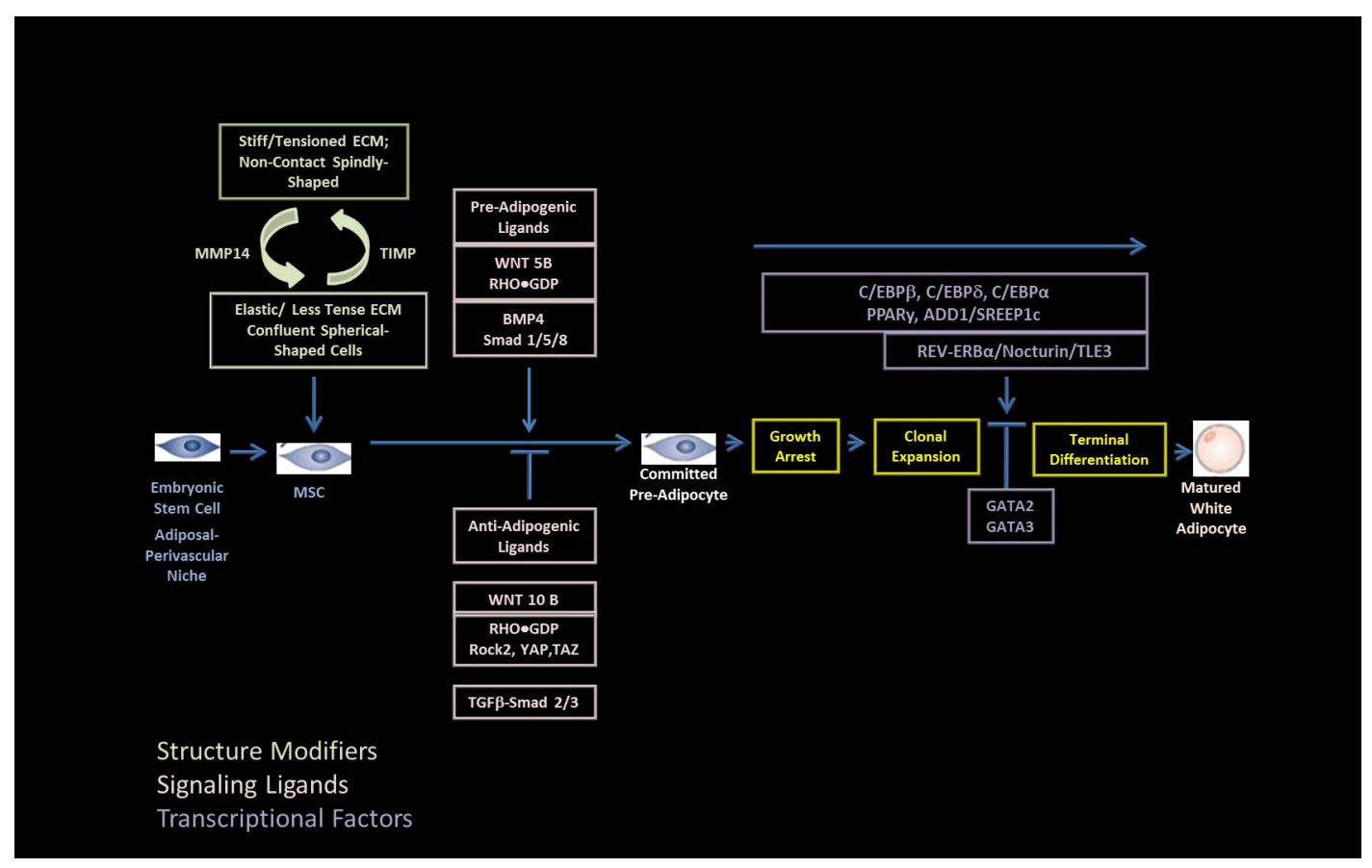

Figure 1. The proliferation and differentiation of embryonic stem cells to mature white adipocytes require a complex integration of changes in the extra-cellular matrix, intracellular architecture, ligand signaling, and transcription regulators. Factors implicated in the stages of adipogenesis are listed as shown: ECM (Extracellular matrix); MMP14 (Matrix metalloproteinase); TIMP (Tissue inhibitors of MMPs); WNT family (Inhibitory canonical WNT 10B or stimulatory non-canonical WNT 5B) Signaling Pathways; RHO family (Inhibitory active RHO+GTP or stimulatory inactive RHO•GDP) signaling pathway; BMP family (Stimulatory bone morphogenetic protein-4) signaling pathway; Smad family (Trans-cytoplasmic protein receptors); Rock2 (RHO-associated kinase); YAP (Yes-associated protein transcriptional factor); TAZ (Transcriptional co-activator and nuclear transporter); TGF family (Transforming growth factors); C/EBP (Transcriptional enhancerbinding proteins $\alpha, \beta, \delta$ ); PPAR $\gamma$ (Transcriptional peroxisome proliferator-activated receptor gamma, a central regulator of differentiation); ADD1/SREEP1c (Transcription factor adipocyte determination and differentiation factor 1; sterol regulatory element binding protein-1); REV-ERB $\alpha$, Nocturin, TLE3 (circadian rhythm co-factors for PPAR $\gamma$ action during terminal differentiation); GATA 2/3 (Inhibitory transcription factors on PPAR $\gamma$ activity).

gand, an alternative pathway of the WNT family can also signal promotion of adipogenesis by blocking the nuclear transference of $\beta$-catenin, impeding the inhibitory pathway of canonical WNT signaling, thereby stimulating adipogenesis to committed preadipocytes [144]. Contemporary studies [131] [145] have shown that the shapes of MSCs likewise regulate the release of pro-adipogenic or anti-adipogenic signals from RHO-family of ligands,which determine MSCs to differentiate along the adipogenic or osteogenic/myogenic lines. In confluent or spherical human MSCs, the inactive form of the RHO ligand, RHO (RHO·GDP), interacts with a p190B RHO specific GTPase-activating protein that advances adipogenesis by inhibiting RHO-associated kinase 2 (ROCK2)mediated activation of actinomycin cytoskeleton, thereby stimulating pro-adipogenic WNT genes toward adipogenesis [131]. In non-confluent fibroblastic-shaped MCSs, however, the active form of the RHO ligand [146], RHO+GTP, interfaces with other factors that lead to osteogenic or myogenic lines, by furthering ROCK2 and actinomycin formation, through the expression of transcriptional factors YAP (Yes-associated protein) and TAZ (transcriptional co-activator and essential nuclear transporter) with anti-adipogenic WNT genes [147].

The afore-mentioned interactive signaling "cocktail" becomes more intricate with the integration of another signaling factor, transforming growth factor- $\beta$ (TGF- $\beta$ ) super family ligands [148] whose family includes, amongst others, bone morphogenetic proteins(BMPs), activins and Nodal that have mixed effects on the commitment of MSCs to adipogenic competency and commitment of preadipocytic cell lines [149] [150]. Functionally, the TGF- $\beta$ ligands are commonly split into two primary branches on the basis of two transmembrane receptors (type Iand type II) [151] with which they initiate signal transduction through cytoplasmic Smad proteins that mediate their signals to target genes. Through the TGF- $\beta$ branch, the tertiary complex ligand (TGF- $\beta$ /activin/Nodal) are obligated first to bind with type II receptors, which must secondarily interact with the type I re- 
ceptor before triggering either the Smad 2 or Smad 3 [151]. The same tertiary complex ligand that uses the BMP branch can bind to either type I or type II receptors before turning on Smads 1/5/8 [152]. The activated Smads proteins from either branches undergo phosphorylation allowing them interface with a common cytoplasmic Smad 4 (Co-Smad) protein [153] thereby permitting its transnuclear passage, in part by TAZ (a nuclear transporter) [154], to express stimulatory or inhibitory transcription effects upon hundreds of target genes. The precise role(s) of TGF $\beta$-Smads, as the canonical member of the superfamily, remains unclear within the framework of adipogenesis. TGF $\beta$ 's influence is predominantly inhibitory in the adipogenesis of 3T3-F442A cells by signaling through Smad 3 which disrupts the upstream function of C/EBPs [155], thereby blocking the downstream transcription of PPAR $\gamma$ for differentiation [156]. In human MSCs, TGF $\beta$-Smad 3 interaction has been observed to signal the WNT pathways [157] that inhibit adipocyte differentiation, emphasizing there are multiple avenues available to mediate TGF $\beta$-Smad's inhibitory effects in adipogenesis [158]. On the other hand, TGF $\beta$-Smads have also been shown to express a positive effect in obesity human and animal studies [132] and promote proliferation of 3T3-F442A preadipocytes [155] [159], while simultaneously inhibiting their differentiation [149]. Similar to TGF $\beta$, activins [160] primarily are inhibitory with positive effects on proliferation of human preadipocytes, but negative on their subsequent differentiation through Smad 2 and C/EBP- $\beta$ mediation rather than through Smad 3, indicating the exquisite preference of the signaling system.

Of the many BMP ligands that regulate adipogenesis through receptors-Smads 1/5/8 interaction, BMP4 has mostly unidirectional positive effects from studies that show direct commitment of C3H10T1/2 pluripotent stem cells to adipocytic lineage [161] [162] and differentiation of MSCs into adipocytes in the absence of standard adipogenic "cocktails" [163] [164]. From proteomic analysis, one of the downstream targets of BMP signaling is the production of cytoskeleton-associated proteins that dramatically change cell shape during adipocyte commitment [165]. Although the relationship between cell shape and extracellular matrix (ECM) to adipogenic regulation remains unclear, these cytoskeletal proteins [lysyl oxidase (Lox), translationally controlled tumor protein 1 (Tpt1) and $\alpha \beta$ crystalline] may determine the ability of MSCs to commit to the adipocyte lineage through cell shape regulation. Unlike other BMP members, such as BMP2, 6, 9, that exhibit mixed effects on adipogenesis, BMP7 has been implicated in supporting brown adipogenesis in pretreated C3H/10T1/2 cells with expression of the mitochondrial uncoupler UCP1 [166], the up-regulation of PPAR $\gamma, \mathrm{C} / \mathrm{EBP}$, Fabp4, and Prdm16 (an early marker of brown adipocytes) [167].

\subsection{Transcriptional Regulation of Induction to Differentiation}

Over the past twenty years significant advances in understanding the molecular transcriptional regulation of adipogenic differentiation has been possible after the establishment of immortal clonal cells lines or cultured preadipocytes from stromal vascular fractions. Although key observations from these systems shed light on the highly orchestrated events converting the spindly preadipocytes to mature round adipocytes, cell lines differentiate exclusively to white adipose tissue, are aneuploidal in genetic composition, and exist outside of their normal extracellular matrix or depot-specific behavioral environments. Nevertheless, transcriptional regulation has received much attention because of its importance in engineering stem cells for regenerative medicine and in understanding fat cell biology to manage health concerns such as obesity and anorexia.

Of the hormonal inducers, inhibitors, promoters, protein kinases, coactivator and others in the transcriptional cascade, key classes of transcriptional factors have been identified that directly regulate the transcriptional process of adipogenesis in a temporal sequence in vitro that may faithfully resemble in vivo events. In cultured cell models, CCAAT/enhancer-binding proteins- $\beta$ and $-\delta(\mathrm{C} / \mathrm{EBP} \beta, \mathrm{C} / \mathrm{EBP} \delta)$ are rapidly expressed first in less than 4 hours after induction during initial growth arrest [168]. Between 14 and 20 hours after induction, C/EBP $\beta$ acquires DNA-binding and phosphorylation concomitant with entry into the brief mitotic clonal expansion phase [169]. Between 28 and 60 hours after induction in permanent growth arrest, C/EBP $\beta$ and C/EBP $\delta$ induce the expression of PPAR $\gamma$ through binding sites on the PPAR $\gamma$ promotor [170] [171]. PPAR $\gamma$ then activates the presence of $\mathrm{C} / \mathrm{EBP} \alpha$, which together transactivate a large group of genes as a positive feedback loop within the cascade to perpetuate the terminally differentiated state [172] [173]. PPAR $\gamma$ is a potent inducer of adipogenesis that includes all aspects of mature fat cell morphological changes, lipid accumulation of insulin sensitivity, and even the induction of transdifferentiation of cultured myoblast to adipocytes, especially in the presence of C/EBP $\alpha$. Another transcription factor, ADD1/SREEP1c (adipocyte determination and differentiation factor 1/sterol regulatory element binding protein-1), has be shown to co-express with PPAR $\gamma$ to result in greater transcriptional ac- 
tivity than PPAR $\gamma$ alone, suggesting a direct stimulatory target to enhance adipocyte differentiation [174]. PPAR $\gamma$ activities may also be positively influenced by other circadian rhythm factors [175], such as REV-ERB $\alpha$ [176], nocturnin [177] and TLE3 [178], which act as co-factors for PPAR $\gamma$ to induce PPAR $\gamma$ and its genomic activities during terminal differentiation. Other transcription factors, such as GATA 2/3 [179], have an inhibitory effect on PPAR $\gamma$ by repressing its activity that permits preadipocytes to proceed into terminal differentiation.

From a whole-genome approach, an improved molecular understanding [180] of the maintenance of mature adipocytes and their major expressions of adipogenic enzymes and synthesis of adipocyte-secreted proteins, such as adipsin [181], adiponectin [182], leptin [183] and resistin [184], are evolving. Investigations [185] [186] that involve the study of a large number of genomic binding sites have indicated that PPAR $\gamma, \mathrm{C} / \mathrm{EBP} \alpha$ and $\mathrm{C} / \mathrm{EBP} \beta$ are all required for sustained expression of PPAR $\gamma$ and C/EBP target genes in mature adipocytes. Such studies on gene overlapping sites have demonstrated that $60 \%$ of the up-regulated genes have binding sites for both PPAR $\gamma$ and $\mathrm{C} / \mathrm{EBP} \alpha$ during terminal differentiation. PPAR $\gamma$ and the family of C/EBPs exhibit positive feedback mechanisms to perpetuate terminal differentiation [172] [187]. Moreover, PPAR $\gamma$ may also engage in DNA looping for long-range gene regulation and opening chromatin for more binding accessibility [188]. On the other hand, when depletion of PPAR $\gamma$ occurs in mature 3T3 adipocytes in culture, the cells express less their adipocytic genes and insulin responses [189]. Deletion of PPAR is lethal in mature white and brown adipocytes in transgenic mouse model [190] [191].

\subsection{White-Brown Adipocyte Development and Plasticity}

As previously mentioned, two main types of adipose tissue, white adipose tissue (WAT) and brown adipose tissue (BAT) have been observed to have different morphological, biochemical and biological functions. Although progenitors of WAT were observed in late gestation [87], their rate of adipogenesis to preadipocyte-commitment and terminal differentiation into mature unilocular adipocytes rapidly escalated within their stromal adipo-vascular compartments to meet the needs of postnatal expansion [192]. In adult humans, WAT represented volumetrically the more abundant adipose tissue and was primarily located in the subcutaneous regions, surrounding visceral organs and in the face. In spite of their similar histological appearances, subcutaneous and visceral WAT exhibited distinct depot-specific metabolic differences, possibly due to different local paracrine signals or to distinct genetic functional programs and took a different and distinct development program during embryonic development [193] [194]. With few mitochondria but laden with variable lipid collections, WAT primarily stored and modulated energy and acted as an endocrine organ through its secretory capabilities [87] [195] [196]. In contrast, the rate of adipogenesis from progenitors to mature multilocular, mitochondrial-laden adipocytes of BAT was believed to surge primarily in utero, possibly to maintain body heat upon birth [197]. BAT provided heat in response to densely packed intracellular mitrochondria and surrounded by a highly vascularized and sympathetically innervated system [198]. BAT's engagement with basal and induced thermal dissipation was due to the presence of UCP1, a unique protein localized in the inner mitochondrial membrane, that uncoupled energy (heat) released to drive mitochondrial respiration from ATP synthesis on adrenergic stimulation [199] [200].

From global gene expression patterns, BAT microanalysis has demonstrated myogenic transcriptional signatures, such as Myf5, MyoD and myogenin, which suggested a close relationship to skeletal muscle [201]. Furthermore, progenitors of myoblast and BAT expressed an identical muscle myogenic factor $\left(\mathrm{MYF}^{+} \mathrm{PAX7}^{+}\right.$) [202], not found in WAT, as late as embryonic day 10.5 [203]. In 2010, Petrovic et al. [204] described a new subset of adipocyte, termed as "brite" (brown-in-white), that were derived from WAT upon prolonged cold exposure or in response to $\beta$-adrenergic signaling. "Brite" adipocytes transformed from mature white adipocytes into brown- like adipocytes by direct differentiation or transdifferentiation, were functionally thermogenic by expression of uncoupling protein 1 (UCP), but failed to express classic brown adipocyte genes [205]. Recent evidence suggested a white-brown plasticity whereby brown adipocytes could be transformed into white adipocytes when energy balance was positive for increased storage capacity or, when necessary, a transformation from white to brown adipocytes for thermogenic purposes [206] [207]. Of all body tissues, adult white adipose tissue possessed the unique capacity to expand and contract by cell number and volume after adulthood was achieved. For example, WAT mass has been recorded from $2-3 \%$ of body weight in conditioned athletes to $60 \%-70 \%$ in morbidly obese adults (normal values: males 9-18\%; females 14\% - 28\%) [208] [209]. Despite these intriguing in vivo advances in tracing adipose lineages and their significant implications for identifying molecular and cellular 
targets against metabolic diseases, such as obesity, type 2 diabetes, cachexia and lipodystrophies, studies on WAT and BAT adipogenesis have been largely confined to in vitro models, especially mouse 3T3-L1 cells [210].

\subsection{Dynamics of Adipocyte Turnover in Humans}

Radioactive tracer turnover studies [211] [212] on fat cell numbers and adipogenesis in humans are not fully understood, but some investigations [213] [214] have suggested that the total adipocyte number increased during newborn, childhood, and adolescence, but became set by early adulthood with the number leveling off and remaining constant throughout adulthood. Although the mature adipocyte number was static in adults, about $10 \%$ of fat cells were renewed annually at all adult ages and levels of body mass index [215]. Presumably, a population of adipose lineage-committed progenitors function to replace dying adipocytes through the lifetime of an individual and to expand by adipogenesis during times of normal growth, excess energy availability or obesity. Resident progenitor cells in humans might normally have a limited proliferative capacity in vivo since two investigations have found that expansion of the resident preadipocyte pool has not been observed in humans with overfeeding [216], and resident preadipocyte numbers are reduced with increasing adiposity [217].

\subsection{Components of Adipose Tissue}

Intact human adipose tissue and, in particular, derived liposuction aspirates, contained a heterogenous mix of indigenous cell types, non-resident cell populations, and constituent extracellular matrix that is intimately and dynamically involved in the growth, proliferation and differentiation of the resident cells. The multiple native cell types included mature adipocytes, preadipocytes, endothelial cells, smooth muscle cells, pericytes, fibroblasts and adipose stem cells (ASCs). The non-indigenous circulating cell types consisted of standard immune cells ( $\beta$ and $\mathrm{T}$ cells, killer cells, mast cells macrophages, monocytes), hematopoietic stem cells, and endothelial stem cells. The extracellular matrix contains, among others, a number of identified collagen types, laminin and fibronectin and an array of $\beta$-transforming growth factors, platelet-derived growth factors and fibroblast growth factors [218]-[220]. Although mature adipocytes represent more than 90\% of tissue volume due to their large size (50 - $130 \mu \mathrm{m}$ diameter) and potential expansion volume [221], their number is calculated to be less than $50 \%$ of a given volume [222]. Adipose tissue is endowed with an abundant microvasculature system whose capillaries are virtually adjacent to individual adipocytes [223]-[225].

\subsection{Adipose-Derived Stem Cells}

Adipose-derived stem cells are fibroblast-like cells, originating from either mesodermal mesenchymal or vascular stem cells and destined for adipogenetic differentiation and maturation. Additional beneficial effects of ASCs are believed to be mediated by released secretory growth factors and cytokines for trophic and vascular effects, including immunosuppressive and anti-inflammatory paracrine actions for local tissue repair. Although adipose-derived stem cells have been one of the most studied adult stem cells, fundamental knowledge of its isolation, characterization, cell-to-cell and paracrine communications in cell culture, translational experiments and clinical practice are lacking. Standardization of protocols for adipose stem cell harvesting, processing, and controlled clinical trials to understand the biological properties of ASCs are being conducted.

\subsection{Roles for Adipose Tissue and Adipose-Derived Stem Cells (ADSCs) in Plastic Surgery}

For over a century, adipose tissue has become the preferred autologous tissue replacement for many reconstructive and aesthetic challenges in plastic surgery, as evidenced by the exponential number of recent publications. Gir, et al. [226] located over 1863 articles up to August 2011 and reported on 37 evidenced-based publications (5 human clinical trials; 32 experimental comparative studies with human fat), using 20 search terms on the PubMed database, that included "autologous fat grafting" and "adipose stem cells." To date there is no published consensus on the optimal method for fat grafting and its retention. Besides its acknowledged attributes as an autogenous graft material, adipose tissue has been recognized as a more attractive supplier of adult adipose-MSCs, more so than bone marrow, for both uncultured/heterogenous stromal vascular fractions (SFVs) and cultured/relative homogenous ASCsin preclinical and clinical studies [227]-[229]. In the 1960s Rodbell and Jones [229] [230] were the first to isolate the sedimented cell fraction, called the stromal vascular fraction (SVF), after collagenase digestion and differential centrifugation of rat fat pads. By the 1970-1980s, the know- 
ledge derived from these earlier preclinical SVF methods was adapted for isolation of human SVFs from within adipose tissue specimens [231] [232], the digested aspirated fat [233]-[235], as well as aspiration fluid [236][238] after tumescent liposuction. Devoid of contaminated erythrocytes and disrupted mature adipocytes, human SVF consisted of a heterogenous cell population of fibroblasts, pericytes, leucocytes, B and T lymphocytes, macrophages, endothelial cells, and "preadipocytes" which are similar if not identical to adipose stem cells (ASCs) [239]-[241]. As a final isolation step, an enriched preadipocyte population within the SVF cells was separated by growth adherence on a tissue culture plastic surface. The isolation, purification and characterization of this adherent cell population (ASCs) within the SVF were defined further by separating the cells based on their expression of cell surface markers [49]. Some of the most useful markers were believed to be ultimately CD31 and human leukocyte antigen (HLA DR), which were molecules normally found on endothelial cells. These two markers separated the cells of the SVF into two subpopulations: the CD31 $/ \mathrm{HLA} \mathrm{DR}^{-} / \mathrm{CD}^{-} 4^{+} / \mathrm{CD}^{-} 5^{-}$populations were the plastic-adherent ADSCs, while the $\mathrm{CD} 31^{+} / \mathrm{HLA} \mathrm{DR}^{+} / \mathrm{CD} 34^{+} / \mathrm{CD} 45^{-}$populations were bona fide endothelial cells [242] [243]. The ASCs exhibited in vitro a more homogeneous immunophenotypic group of cells with similar, but not identical surface antigens, differentiation lineages, regenerative capacity and an array of paracrine cytokine and growth factors to the BM-BMCs [244]-[251].

ASCs can differentiate in vitro into many lineages, including adipocytes and vascular cells [107], secreting an array of cytokines and growth factors [108], and displaying regenerative capabilities in preclinical animal models of human disease [252]. Although some in vivo studies suggested that ASCs expressed their regenerative potential by replenishing damaged or apoptotic cell populations along their particular cell differentiation pathway, animal studies have not consistently confirmed this hypothesis. In fact, many investigators give more weight to the importance of cell signaling molecules (such as VEGF growth factors, prostaglandin $\mathrm{E}_{2}$ immunomodulatory factors) and small proteins (cytokines), released by adipose-derived stem cells, than cell replication to account for tissue recovery by emphasizing their paracrine functions of cellular repair by host angiogenesis/vasculogenesis and suppression of inflammation by the host-derived cells [244] [245] [250] [253] [254].

As mentioned above, elucidation of the cellular and molecular biology of adipogenesis continues, along with an explosion in the basic science and clinical interests in adipose-derived cells for reconstructive and aesthetic purposes. The potential for ASCs to differentiate into endothelial cells for vascular engineering [255]-[257] and for seeding on recipient matrix and supportive substrates for tissue engineering [258]-[260] have generated numerous promising investigations for clinical usage. For example, Kang et al. [261] observed the contributions of ASCs for neoangiogenesis on a silk protein scaffold embedded with both ASCs and human umbilical vein endothelial cells. These findings may provide a stem cell-based molecular mechanism to optimize the vascularity, and thereby, diffusion of nutrients and oxygen, in inadequate vascular networks after fat grafting [262]-[267], radiation injury [268] or trauma [269].

Promising outcomes have also been observed with the use of ASCs for the regeneration of tissue types other than adipose tissue. ASCs have demonstrated in murine models a positive regenerative effect on facial nerve injury with axonal growth and myelin sheath formation [270], increased skin graft take [271], and decreased myocardial infarct size [272]. With avascular femoral head necrosis and degeneration of knee meniscal cartilage, a human pilot study [273] demonstrated MRI filling of bony and cartilaginous defects along with improved mobility after direct injection of ASCs mixed with platelet-rich plasma, hyaluronic acid, and calcium chloride into the diseased sites.

In the United States, U.S. Food and Drug Administration regulation of fat grafting and associated used of isolated stem cells from autologous tissue continues to be controversial. In short, all ASC isolation methods by enzyme digestion and associated devices that participate in the proliferation and differentiation of ASCs prior to usage in patients require U.S. FDA oversight, validation and premarket approval for safety concerns under federal regulations 21 CFR 1271.3(d) and Public Health Safety Act, Section 351 [274] [275]. Currently, the U.S. FDA has not given approval to any stem cell isolation devices or ASC procedures for stem cell-based productsintended for implantation, transplantation, infusion or transfer into a human recipient [276]. There are stem cell registered studies on the National Institutes of Health Web-based registry (ClinicalTrials.gov) as listed in countries in Asia, Europe and South America.

\section{Conclusion}

Although the promise of beneficial effects of autologous fat grafting has been observed over the century, no major advances have occurred. With the expanding use of clinical fat grafting applications and the therapeutic 
relevance in regenerative medicine through SVF and ASCs, this review of fat cell and ASC biology may provide a basic understanding for clinicians to improve their knowledge, rationale and clinical outcomes. Despite this promise, until further research elucidates the complex molecular regulation controlling adipogenesis and ASCs' significance, clinicians and scientist will not be able to harvest their true potential in plastic and non-plastic surgery applications.

\section{Acknowledgements}

The author thanks Sharon Cuellar for creating the artwork.

\section{Disclosures}

The author declared no conflicts of interest in respect to the authorship and publication of this article.

\section{Funding}

The author received no financial support for the authorship of this article.

\section{References}

[1] Neuber, F. (1893) Fettransplantation Bericht uber die Verhandlungen der Deutscht Gesellsch Chir. Zentralblatt fur Chirurgie, 22, 66.

[2] Billings, E. and May, J.W. (1989) Historical Review and Present Status of Free Fat Graft Autotransplantation Inplasticand Reconstructive Surgery. Plastic and Reconstructive Surgery, 83, 368-381. http://dx.doi.org/10.1097/00006534-198902000-00033

[3] Sommer, B. and Sattler, G. (2000) Current Concepts of Fat Graft Survival: Histology of Aspirated Adipose Tissue and Review of the Literature. Dermatologic Surgery, 26, 1159-1166. http://dx.doi.org/10.1046/j.1524-4725.2000.00278.x

[4] Pu, L.L.Q. (2012) Towards More Rationalized Approach to Autologous Fat Grafting. Journal of Plastic, Reconstructive Aesthetic Surgery, 65, 413-419. http://dx.doi.org/10.1016/j.bjps.2011.09.033

[5] Illouz, Y. (1986) The Fat Cell “Graft”: A New Technique to Fill Depressions. Plastic and Reconstructive Surgery, 78, 122-123. http://dx.doi.org/10.1097/00006534-198607000-00028

[6] Fournier, P.F. (1985) Microlipoextration et microlipoinjection. Rev Chirurgie Esthetique Lang France, 10, 36-40.

[7] Klein, J. (1990) The Tumescent Technique: Anesthesia and Modified Liposuction Technique. Dermatologic Clinics, 8, 425-437.

[8] Kaufman, M.R., Miller, T.A., Huang, C., Roostaien, J., Wasson, K.L., Ashley, R. and Bradley, J. (2007) Autologous Fat Transfer for Facial Contouring: Is There Science behind the Art? Plastic and Reconstructive Surgery, 119, 22872297. http://dx.doi.org/10.1097/01.prs.0000260712.44089.e7

[9] Peer, L.A. (1950) Loss of Weight and Volume in Human Fat Grafts. Plastic and Reconstructive Surgery, 5, $217-230$. http://dx.doi.org/10.1097/00006534-195003000-00002

[10] May, J.W. (1990) Comparative Study of Survival of Autologous Adipose Tissue Taken and Transplanted by Different Techniques (Discussion). Plastic and Reconstructive Surgery, 85, 387-389. http://dx.doi.org/10.1097/00006534-199003000-00008

[11] Mojallal, A. and Foyatier, J.L. (2004) The Effect of Different Factors on the Survival of Transplanted Adipocytes. Annales de Chirurgie Plastique Esthétique, 49, 426-436. http://dx.doi.org/10.1016/j.anplas.2004.08.005

[12] Coleman, S.R. (1997) Facial Recontouring with Lipostructure. Clinics in Plastic Surgery, 24, 347.

[13] Ranmalho-Santos, M. and Willenbring, H. (2007) On the Origin of the Term “Stem Cell”. Cell Stem Cell, 1, 35-38. http://dx.doi.org/10.1016/j.stem.2007.05.013

[14] Morrison, S.J., Shah, N.M. and Anderson, D.J. (1997) Regulatory Mechanisms in Stem Cell Biology. Cell, 88, 287298. http://dx.doi.org/10.1016/S0092-8674(00)81867-X

[15] Becker, A.J., McCulloch, E.A. and Till, J.E. (1963) Cytological Demonstration of the Clonal Nature of Spleen Colonies Derived from Transplanted Mouse Marrow Cells. Nature, 197, 452-454. http://dx.doi.org/10.1038/197452a0

[16] Till, J.E. and McCulloch, E.A. (1961) A Direct Measurement of the Radiation Sensitivity of Normal Mouse Bone Marrow Cells. Radiation Research, 14, 213-222. http://dx.doi.org/10.2307/3570892

[17] Till, J.E., McCulloch, E.A. and Siminovitch, L. (1964) A Stochastic Model of Stem Cell Proliferation, Based on the Growth of Spleen Colony-Forming Cells. Proceedings of the National Academy of Sciences of the United States of America, 51, 29-36. http://dx.doi.org/10.1073/pnas.51.1.29 
[18] Friedenstein, A.J., Petrakova, K.V., Kurolesova, A.I. and Frolova, G.P. (1968) Heterotopic of Bone Marrow. Analysis of Precursor Cells for Osteogenic and Hematopoietic Tissues. Transplantation, 6, 230-247.

[19] Friedenstein, A.J., Latzinik, N.W., Grosheva, A.G. and Gorskaya, U.F. (1982) Marrow Microenvironment Transfer by Heterotopic Transplantation of Freshly Isolated and Cultured Cells in Porous Sponges. Experimental Hematology, 10, 217-227.

[20] Amsel, S. and Dell, E.S. (1972) Bone Formation by Hemopoietic Tissue: Separation of Preosteoblast from Hemopoietic Stem Cell Function in the Rat. Blood, 39, 267-273.

[21] Pereira, R.F., Halford, K.W., O’Hara, M.D., Leeper, D.B., Sokolov, B.P., Pollard, M.D., et al. (1995) Cultured Adherent Cells from Marrow Can Serve as Long-Lasting Precursor Cell for Bone, Cartilage, and Lung in Irradiated Mice. Proceedings of the National Academy of Sciences of the United States of America, 92, 4857-4861. http://dx.doi.org/10.1073/pnas.92.11.4857

[22] da Silva Meirelles, L., Chagastelles, P.C. and Nardi, N.B. (2006) Mesenchymal Stem Cells Reside in Virtually All Post-Natal Organs and Tissues. Journal of Cell Science, 119, 2204-2213. http://dx.doi.org/10.1242/jcs.02932

[23] Pittenger, M.F., Mackay, A.M., Beck, S.C., Jaiswal, R.K., Douglas, R., Mosca, J.D., et al. (1999) Multilineage Potential of Adult Human Mesenchymal Stem Cells. Science, 284, 143-147. http://dx.doi.org/10.1126/science.284.5411.143

[24] Caplan, A.I. (2007) Adult Mesenchymal Stem Cells for Tissue Engineering versus Regenerative Medicine. Journal of Cellular Physiology, 231, 341-347. http://dx.doi.org/10.1002/jcp.21200

[25] Synkers, S., De Kock, H., Rogiers, V. and Vanhaecke, T. (2009) In Vitro Differentiation of Embryonic and Adult Stem Cells Intohepatocytes: State of the Art. Stem Cells, 27, 577-605.

[26] Arthur, A., Rychkov, G., Shi, S., Koblar, S.A. and Gronthos, S. (2008) Adult Human Dental Pulp Stem Cells Differentiate toward Functionally Active Neurons under Appropriate Environmental Cues. Stem Cells, 26, 1787-1795. http://dx.doi.org/10.1634/stemcells.2007-0979

[27] Crisan, M., Yap, S., Casteilla, L., Chen, C.-W., Corselli, M., Park, T.S., et al. (2008) A Perivascular Origin for Mesenchymal Stem Cells in Multiplehuman Organs. Cell Stem Cell, 3, 301-313. http://dx.doi.org/10.1016/j.stem.2008.07.003

[28] Kuznetsov, S.A., Krebsbach, P.H., Satomura, K., Kerr, J., Riminucci, M., Benayahu, D. and Robey, P.G. (1997) Single-Colony Derived Strains of Human Marrow Stromal Fibroblasts Form Bone after Transplantation in Vivo. Journal of Bone and Mineral Research, 12, 1335-1347. http://dx.doi.org/10.1359/jbmr.1997.12.9.1335

[29] De Bari, C., Dell’Accio, F., Tylzanowski, P. and Luyten, F.P. (2001) Multipotent Mesenchymal Stem Cells from Adulthuman Synovial Membrane. Arthritis \& Rheumatology, 44, 1928-1942. http://dx.doi.org/10.1002/1529-0131(200108)44:8<1928::AID-ART331>3.0.CO;2-P

[30] Miura, M., Gronthos, S., Zhao, M.R., Lu, B., Fisher, L.W., Robey, P.G. and Shi, S.T. (2003) Shed: Stem Cells from Human Exfoliated Deciduous Teeth. Proceedings of the National Academy of Sciences of the United States of America, 100, 5807-5812. http://dx.doi.org/10.1073/pnas.0937635100

[31] Belicchi, M., Pisati, F., Lopa, R., Porretti, L., Fortunato, F., Sironi, M., et al. (2004) Human Skin-Derived Stem Cells Migrate throughout Forebrain and Differentiate into Astrocytes after Injection into Adult Mouse Brain. Journal of Neuroscience Research, 77, 475-486. http://dx.doi.org/10.1002/jnr.20151

[32] Seo, B.M., Miura, M., Gronthos, S., Bartold, P.M., Batouli, S., Brahim, J., et al. (2004) Investigation of Multipotent Postnatal Stem Cells from Humanperiodontal Ligament. The Lancet, 364, 149-155. http://dx.doi.org/10.1016/S0140-6736(04)16627-0

[33] Song, L., Young, N.J., Webb, N.E. and Tuan, R.S. (2005) Origin and Characterization of Multipotential Mesenchymal Stemcells Derived from Adult Human Trabecular Bone. Stem Cells and Development, 14, 712-721. http://dx.doi.org/10.1089/scd.2005.14.712

[34] Baksh, D., Yao, R. and Tuan, R.S. (2007) Comparison of Proliferative and Multilineage Differentiation Potential of Human Mesenchymal Stem Cells Derived from Umbilical Cord and Bone Marrow. Stem Cells, 25, 1384-1392. http://dx.doi.org/10.1634/stemcells.2006-0709

[35] Musina, R.A., Bekchanova, E.S. and Sukhikh, G.T. (2005) Comparison of Mesenchymal Stem Cells Obtained from Different Human Tissues. Bulletin of Experimental Biology and Medicine, 139, 504-509. http://dx.doi.org/10.1007/s10517-005-0331-1

[36] Choi, Y.S., Noh, S.E., Lim, S.M., Lee, C.-W., Kim, C.-S., Im, M.-W., et al. (2008) Multipotency and Growth Characteristic of Periosteum-Derived Progenitor Cells for Chondrogenic, Osteogenic, and Adipogenic Differentiation. Biotechnology Letters, 30, 593-601. http://dx.doi.org/10.1007/s10529-007-9584-2

[37] Bianco, P., Robey, P.G. and Simmons, P.J. (2008) Mesenchymal Stem Cells: Revisiting History, Concepts, and Assays. Cell Stem Cell, 2, 313-319. http://dx.doi.org/10.1016/j.stem.2008.03.002 
[38] Owen, M. (1988) Marrow Stromal Stem Cells. Journal of Cell Science, 10, 63-76. http://dx.doi.org/10.1242/jcs.1988.Supplement_10.5

[39] Caplan, A.I. (1991) Mesenchymal Stem Cells. Journal of Orthopaedic Research, 9, 641-650. http://dx.doi.org/10.1002/jor.1100090504

[40] Jones, E. and McGonagle, D. (2008) Human Bone Marrow Mesenchymal Stem in Vivo. Rheumatology (Oxford), 47, 126-131. http://dx.doi.org/10.1093/rheumatology/kem206

[41] Dominici, M., Paolucci, P., Conte, P. and Horwitz, E.M. (2009) Heterogeneity Of Multipotent Mesenchymal Stromal Cells: From Stromal Cells to Stem Cells and Vice Versa. Transplantation, 87, S36-42. http://dx.doi.org/10.1097/TP.0b013e3181a283ee

[42] Gronthos, S. and Zannettino, A.C. (2008) A Method to Isolate and Purify Human Bone Marrow Stromal Stem Cells. Methods in Molecular Biology, 449, 45-57. http://dx.doi.org/10.1007/978-1-60327-169-1_3

[43] Buhring, H.J., Battula, V.J., Treml, S., Schewe, B., Kanz, L. and Vogel, W. (2007) Novel Markers for the Prospective Isolation of Human MSC. Annals of the New York Academy of Sciences, 1106, 262-271. http://dx.doi.org/10.1196/annals.1392.000

[44] Jones, E.A., Kinsey, S.E., English, A., Jones, R.A., Straszynski, L., Meredith, D.M., et al. (2008) Isolation and Characterization of Bone Marrow Multipotential Mesenchymal Progenitor Cells. Arthritis \& Rheumatology (Oxford), 46, 3349-3360.

[45] Donald, G.P. and Darwin, J.P. (2007) Concise Review: Mesenchymal Stem/Multipotent Stromal Cells: The State of Transdifferentiation and Modes of Tissue Repair-Current Views. Stem Cells, 25, 2896-2902.

[46] Kahn, A.J. and Simmons, D.J. (2007) Chondrocyte-to-Osteocyte Transformation in Grafts of Perichondrium-Free Epiphyseal Cartilage. Clinical Orthopaedics and Related Research, No. 129, 299-304.

[47] Bennett, J.H., Joyner, C.J., Triffitt, J.T., et al. (1991) Adipocytic Cells Cultured from Marrow Have Osteogenic Potential. Journal of Cell Science, 99, 131-139.

[48] Horwitz, E.M., Le Blanc, K., Dominici, M., et al. (2005) Clarification of the Nomenclature for MSC: The International Society for Cellular Therapy Position Statement. Cytotherapy, 7, 393-395. http://dx.doi.org/10.1080/14653240500319234

[49] Dominici, M., Le Blanc, K., Mueller, I., et al. (2006) Minimal Criteria for Defining Multipotent Mesenchymal Stromal Cells. The International Society for Cellular Therapy Position Statement. Cryotherapy, 8, 315-317. http://dx.doi.org/10.1080/14653240600855905

[50] Bernardo, M.E., Locatelli, F. and Fibbe, W.E. (2009) Mesenchymal Stromal Cells. Annals of the New York Academy of Sciences, 1176, 101-117. http://dx.doi.org/10.1111/j.1749-6632.2009.04607.x

[51] Prockop, D.J., Brenner, M., Fibbe, W.E., et al. (2010) Defining the Risks of Mesenchymal Stromal Cell Therapy. Cytotherapy, 12, 576-578. http://dx.doi.org/10.3109/14653249.2010.507330

[52] Kasper, G., Dankert, N., Tuischer, J., et al. (2007) Mesenchymal Stem Cells Regulate Angiogenesis According to Their Mechanical Environment. Stem Cells, 25, 903-910. http://dx.doi.org/10.1634/stemcells.2006-0432

[53] Horwitz, E.M. and Dominici, M. (2008) How Do Mesenchymal Stromal Cells Exert Their Therapeutic Benefit? Cytotherapy, 10, 771-774. http://dx.doi.org/10.1080/14653240802618085

[54] Rasmusson, I., Ringden, O., Sundberg, B., et al. (2005) Mesenchymal Stem Cells Inhibit Lymphocyte Proliferation by Mitogens and Alloantigens by Different Mechanisms. Experimental Cell Research, 305, 33-41. http://dx.doi.org/10.1016/j.yexcr.2004.12.013

[55] Bartholomew, A., Sturgeon, C., Siatskas, M., et al. (2002) Mesenchymal Stem Cells Suppress Lymphocyte Proliferation in Vitro and Prolong Skin Graft Survival in Vivo. Experimental Hematology, 30, 42-48. http://dx.doi.org/10.1016/S0301-472X(01)00769-X

[56] Sundin, M., D’arcy, P., Johansson, C.C., et al. (2001) Multipotent Mesenchymal Stromal Cells Express FoxP3: A Marker for the Immunosuppressive Capacity? Journal of Immunotherapy, 34, 647-659.

[57] Le Blanc, K., Frassoni, F., Ball, L., et al. (2008) Mesenchymal Stem Cells for Treatment of Steroid-Resistant, Severe, Acute Graft-versus-Host Disease: A Phase II Study. The Lancet, 371, 1579-1586. http://dx.doi.org/10.1016/S0140-6736(08)60690-X

[58] Weng, J.Y., Du, X., Geng, S.X., et al. (2010) Mesenchymal Stem as Salvage Treatment for Refractory Chronic GVHD. Bone Marrow Transplantation, 45, 1732-1740. http://dx.doi.org/10.1038/bmt.2010.195

[59] Zhou, H., Guo, M., Bian, C., et al. (2010) Efficacy of Bone Marrow-Derived Mesenchymal Stem Cells in the Treatment of Sclerodermatous Chronic Graft-versus-Host Disease: Clinical Report. Biology of Blood and Marrow Transplantation, 16, 403-412. 
[60] Duijvestein, M., Vos, A.C., Roelofs, H., et al. (2010) Autologous Bone Marrow-Derived Mesenchymal Stromal Cell Treatment for Refractory Luminal Crohn’s Disease: Results of a Phase I Study. Gut, 59, 1662-1669. http://dx.doi.org/10.1136/gut.2010.215152

[61] Mallam, E., Kemp, K., Wilkins, A., et al. (2010) Characterization of in Vitro Expanded Bone Marrow-Derived Mesenchymal Stem Cells from Patients with Multiple Sclerosis. Multiple Sclerosis Journal, 62, 909-918. http://dx.doi.org/10.1177/1352458510371959

[62] Sun, L., Wang, D., Liang, J., et al. (2010) Umbilical Cord Mesenchymal Stem Cell Transplantation in Severe and Refractory Systemic Lupus Erythematosus. Arthritis \& Rheumatology, 62, 2467-2475. http://dx.doi.org/10.1002/art.27548

[63] Zhang, H., Zeng, X. and Sun, L. (2010) Allogenic Bone-Marrow-Derived Mesenchymal Cells Transplantation as a Novel Therapy for Systemic Lupus Erythematosus. Expert Opinion on Biological Therapy, 10, 701-709. http://dx.doi.org/10.1517/14712591003769816

[64] Kuroda, R., Ishida, K., Matsumoto, T., et al. (2007) Treatment of a Full-Thickness Articular Cartilage Defect in the Femoral Condyle of an Athlete with Autologous Bone-Marrow Stromal Cells. Osteoarthritis and Cartilage, 15, 226231. http://dx.doi.org/10.1016/j.joca.2006.08.008

[65] Horwitz, E.M., Gordon, P.L., Koo, W.K.K., et al. (2002) Isolated Allogeneic Bone Marrow-Derived Mesenchymal Cells Engraft and Stimulate Growth in Children with Osteogenesis Imperfecta: Implications for Cell Therapy of Bone. Proceedings of the National Academy of Sciences of the United States of America, 99, 8932-8937. http://dx.doi.org/10.1073/pnas.132252399

[66] Chen, S.L., Feng, W.W., Ye, F., et al. (2006) Intracoronary Transplantation of Autologous Bone Marrow Mesenchymal Stem Cells for Ischemic Cardiomyopathy Due to Isolated Chronic Occluded Left Anterior Descending Artery. Journal of Invasive Cardiology, 18, 552-556.

[67] Hu, X., Yu, S.P., Fraser, J.L., et al. (2008) Transplantation of Hypoxia-Preconditioned Mesenchymal Stem Cells Improves Infarcted Heart Function via Enhanced Survival of Implanted Cells and Angiogenesis. The Journal of Thoracic and Cardiovascular Surgery, 135, 799-808. http://dx.doi.org/10.1016/j.jtcvs.2007.07.071

[68] Hare, J.M., Traverse, J.H., Henry, T.D., et al. (2009) A Randomized, Double-Blind, Placebo-Controlled, Dose-Escalation Study of Intravenous Adult Human Mesenchymal Stem Cells (Prochymal) after Acute Myocardial Infarction. Journal of the American College of Cardiology, 54, 2277-2288. http://dx.doi.org/10.1016/j.jacc.2009.06.055

[69] Lee, P.H., Kim, H.W., Band, O.Y., et al. (2008) Autologous Mesenchymal Stem Cell Therapy Delay the Progress of Neurological Defects in Patients with Multiple Systemic Atrophy. Clinical Pharmacology \& Therapeutics, 83, 723-730. http://dx.doi.org/10.1038/sj.clpt.6100386

[70] Lee, J.S., Hong, J.M., Moon, G., et al. (2010) A Long-Term Follow-Up Study of Intravenous Autologous Mesenchymal Stem Cell Transplantation in Patients with Ischemic Stroke. Stem Cells, 28, 1099-1106. http://dx.doi.org/10.1002/stem.430

[71] Anna, G., John, D., Jean, F., et al. (2008) Initial Report on a Phase I Clinical Trial: Prevention and Treatment of Post-Operative Acute Kidney Injury with Allogeneic Mesenchymal Stem Cells in Patients Who Require On-Pump Cardiac Surgery. Cellular Therapy and Transplantation, 1, 31-35.

[72] Caimi, P.F., Reese, J., Lee, Z.H. and Lazarus, H. (2010) Emerging Therapeutic Approaches for Multipotent Mesenchymal Stromal Cells (MSCs). Current Opinion in Hematology, 17, 505-513. http://dx.doi.org/10.1097/MOH.0b013e32833e5b18

[73] Larsen, S. and Lewis, I.D. (2011) Potential Therapeutic Applications of Mesenchymal Stromal Cells. Pathology, 43, 592-604.

[74] Aldahmash, A., Zaher, W., Al-Nbaheen, M., et al. (2012) Human Stromal (Mesenchymal) Stem Cells: Basicbiology and Current Clinical Use for Tissue Regeneration. Annals of Saudi Medicine, 32, 68-77.

[75] Lafontan, M. (2012) Historical Perspectives in Fat Biology: The Fat Cell as a Model for the Investigation of Hormonal and Metabolic Pathways. American Journal of Physiology: Cell Physiology, 302, C327-C359. http://dx.doi.org/10.1152/ajpcell.00168.2011

[76] Martin, R.J., Hausman, G.J. and Hauman, D.B. (1998) Regulation of Adipose Cell Development in Utero. Proceedings of the Society for Experimental Biology and Medicine, 219, 200-210. http://dx.doi.org/10.3181/00379727-219-44333

[77] Atanassova, P.K. (2003) Formation of the Basal Lamina in Human Embryonal Adipose Cells—Immunohistochemical and Ultrastructural Evidence. Folia Medica (Plovdiv), 45, 31-35.

[78] Napolitano, L. (1963) The Differentiation of White Adipose Cells. An Electron Microscope Study. The Journal of Cell Biology, 18, 663-679. http://dx.doi.org/10.1083/jcb.18.3.663

[79] Tadeschi, C.G. (1970) The Fat Cell Origin and Structure. Connecticut Medicine, 24, 33-40. 
[80] Hausman, G.J., Campion, D.R. and Martin, R.J. (1980) Search for the Adipocyte Precursor Cell and Factors That Promote Its Differentiation. The Journal of Lipid Research, 21, 743-757.

[81] Cinti, S., Cigolini, M., Bosello, O., et al. (1984) A Morphological Study of the Adipocyte Precursor. Journal of Submicroscopic Cytology, 16, 243-251.

[82] Diaz-Flores, L.D., Gutierrez, R., Madrid, J.F., et al. (2009) Pericytes. Morphology, Interactions and Pathology in a Quiescent and Activated Mesenchymal Cell Niche. Histology and Histopathology, 24, 909-969.

[83] Sengenes, C., Lolmede, K., Zakaroff-Girard, A., et al. (2005) Preadipocytes in the Human Subcutaneous Adipose Tissue Display Distinct Features from the Adult Mesenchymal and Hematopoietic Stem Cells. Journal of Cellular Physiology, 205, 114-122. http://dx.doi.org/10.1002/jcp.20381

[84] Rodenheffer, M.S., Birsoy, K. and Friedman, J.J.M. (2008) Identification of White Adipocyte Progenitor Cells in Vivo. Cell, 135, 240-249. http://dx.doi.org/10.1016/j.cell.2008.09.036

[85] Zimmerlin, L., Donnenberg, V.S., Pfeifer, M.E., et al. (2010) Stromal Vascular Progenitors in Adult Human Adipose Tissue. Cytometry A, 77, 22-30.

[86] Schulz, T.Z., Huang, T.L., Tran, T.T., et al. (2011) Identification of Inducible Brown Adipocyte Progenitors Residing in Skeletal Muscle and White Fat. Proceedings of the National Academy of Sciences of the United States of America, 108, 143-148. http://dx.doi.org/10.1073/pnas.1010929108

[87] Tang, W., Zeve, D., Suh, J.M., Bosnakovski, D., Kyba, M., Hammer, R.E., Tallquist, M.D. and Graff, J.M. (2008) White Fat Progenitor Cells Reside in the Adipose Vasculature. Science, 322, 583-586. http://dx.doi.org/10.1126/science.1156232

[88] Galli, D., Innocenzi, A., Staszewsky, L., et al. (2005) Mesoangioblasts, Vessel-Associated Multipotent Stem Cells, Repair the Infarcted Heart by Multiple Cellular Mechanisms. A Comparison with Bone Marrow Progenitors, Fibroblasts, and Endothelial Cells. Arteriosclerosis, Thrombosis, and Vascular Biology, 25, 692-697. http://dx.doi.org/10.1161/01.ATV.0000156402.52029.ce

[89] Traktuev, D.O., Merfeld-Clauss, S., Li, J., et al. (2008) A Population of Multipotent CD34-Positive Adipose Stromal Cells Share Pericyte and Mesenchymal Surface Markers, Reside in a Periendothelial Location, and Stabilize Endothelial Networks. Circulation Research, 102, 77-85. http://dx.doi.org/10.1161/CIRCRESAHA.107.159475

[90] Amos, P.J., Shang, H., Bailey, A.M., et al. (2008) IFATS Collection: The Role of Human Adipose-Derived Stromal Cells in Inflammatory Microvascular Remodeling and Evidence of a Perivascular Phenotype. Stem Cells, 26, 26822690. http://dx.doi.org/10.1634/stemcells.2008-0030

[91] Zannettino, A.C., Paton, S., Arthur, A., et al. (2008) Multipotential Human Adipose-Derived Stromal Stem Cells Exhibit a Perivascular Phenotype in Vitro and in Vivo. Journal of Cellular Physiology, 214, 413-421. http://dx.doi.org/10.1002/jcp.21210

[92] Bautch, V.L. (2011) Stem Cells and the Vasculature. Nature Medicine, 17, 1437-1443. http://dx.doi.org/10.1038/nm.2539

[93] Psaltis, P.J., Harbuzariu, A., Delacroix, S., et al. (2011) Resident Vascular Progenitor Cells-Diverse Origins, Phenotype, and Function. Journal of Cardiovascular Translational Research, 4, 161-176. http://dx.doi.org/10.1007/s12265-010-9248-9

[94] Ergun, S., Tilki, D. and Klein, D. (2011) Vascular Wall as a Reservoir for Different Types of Stem and Progenitor Cells. Antioxidants \& Redox Signaling, 15, 981-995. http://dx.doi.org/10.1089/ars.2010.3507

[95] Bostom, K.I., Garfinkel, A., Yao, Y.C. and Jumabay, M. (2012) Concise Review: Applying Stem Cell Biology to Vascular Structures. Stem Cells, 30, 386-391. http://dx.doi.org/10.1002/stem.1027

[96] Doherty, M.J., Ashton, B.A., Walsh, S., et al. (1998) Vascular Pericytes Express Osteogenic Potential in Vitro and in Vivo. Journal of Bone and Mineral Research, 13, 828-838. http://dx.doi.org/10.1359/jbmr.1998.13.5.828

[97] Farrington-Rock, C., Crofts, N.J., Doherty, M.J., et al. (2003) Chondrogenic and Adipogenic Potential of Microvascular Pericytes. Circulation Research, 92, 1123-1129.

[98] Dellavalle, A., Sampaolesi, M., Tonlorenzi, T., et al. (2007) Pericytes of Human Skeletal Muscle Are Myogenic Precursors Distinct from Satellite Cells. Nature Cell Biology, 9, 255-267. http://dx.doi.org/10.1038/ncb1542

[99] Lin, G., Garcia, M., Ning, H., et al. (2008) Defining Stem and Progenitor Cells with Adipose Tissue. Stem Cells and Development, 17, 1053-1063. http://dx.doi.org/10.1089/scd.2008.0117

[100] Corselli, M., Chen, C.W., Sun, B., et al. (2010) The Tunica Adventitia of Human Arteries and Veins as a Source of Mesenchymal Stem Cells. Stem Cells and Development, 21, 1299-1308. http://dx.doi.org/10.1089/scd.2011.0200

[101] Campagnolo, P., Cessellili, D., Al Haj-Zen, A., et al. (2010) Human Adult Vena Saphena Contains Perivascular Cells Endowed with Clonongenic And Proangiogenic Potential. Circulation, 121, 1735-1745. http://dx.doi.org/10.1161/CIRCULATIONAHA.109.899252 
[102] Majesky, M.W., Dong, X.R., Hoglund, V., Mahoney Jr., W.M. and Daum, G. (2011) The Adventitia: A Dynamic Interface Containing Resident Progenitor Cells. Arteriosclerosis, Thrombosis, and Vascular Biology, 31, 1530-1539. http://dx.doi.org/10.1161/atvbaha.110.221549

[103] Lin, C.-S. and Lue, T.F. (2013) Defining Vascular Stem Cells. Stem Cells and Development, 22, 1018-1024. http://dx.doi.org/10.1089/scd.2012.0504

[104] Medici, D., Shore, E.M., Lounev, V.Y., et al. (2010) Conversion of Vascular Endothelial Cells into Multipotent StemLike Cells. Nature Medicine, 16, 1400-1406. http://dx.doi.org/10.1038/nm.2252

[105] Gupta, R.K., Mepani, R.J., Kleiner, S., et al. (2012) Zfp423 Expression Identifies Committed Preadipocytes and Localizes to Adipose Endothelial and Perivascular Cells. Cell Metabolism, 15, 230-239. http://dx.doi.org/10.1016/j.cmet.2012.01.010

[106] Tran, K.-V., Gealekman, O., Frontini, A., et al. (2012) The Vascular Endothelium of the Adipose Tissue Give Rise to Both White and Brown Fat Cells. Cell Metabolism, 15, 222-229. http://dx.doi.org/10.1016/j.cmet.2012.01.008

[107] Planat-Bernard, V., Silvestre, J.S., Cousin, B., et al. (2004) Plasticity of Human Adipose Lineage Cells toward Endothelial Cells: Physiological and Therapeutic Perspectives. Circulation, 109, 656-663. http://dx.doi.org/10.1161/01.CIR.0000114522.38265.61

[108] Miranville, A., Heechen, C., Sengenes, C., et al. (2004) Improvement of Postnatal Neovascularization by Human Adipose Tissue-Derived Stem Cells. Circulation, 110, 349-355. http://dx.doi.org/10.1161/01.CIR.0000135466.16823.D0

[109] Cao, Y., Sun, Z., Liao, L., et al. (2005) Human Adipose Tissue-Derived Stem Cells Differentiate into Endothelial Cells in Vitro and Improve Postnatal Neovascularization in Vivo. Biochemical and Biophysical Research Communications, 332, 370-379. http://dx.doi.org/10.1016/j.bbrc.2005.04.135

[110] Merfeld-Clauss, S., Gollahalli, N., March, K.L., et al. (2010) Adipose Tissue Progenitor Cells Directly Interact with Endothelial Cells to Induce Vascular Network Formation. Tissue Engineering Part A, 16, 2953-2966. http://dx.doi.org/10.1089/ten.tea.2009.0635

[111] Traktuev, D.O., Prater, D.N., Merfeld-Clauss, S., et al. (2009) Robust Functional Vascular Network Formation in Vivo by Cooperation of Adipose Progenitor and Endothelial Cells. Circulation Research, 104, 1410-1420. http://dx.doi.org/10.1161/CIRCRESAHA.108.190926

[112] Castro-Malaspina, H., Gay, R.E., Resnick, G., et al. (1980) Characterization of Human Bone Marrow Fibroblasts Colony-Forming Cells (CFU-F) and Their Progeny. Blood, 56, 289-301.

[113] Hong, K.M., Buridick, M.D., Phillips, R.J., et al. (2005) Characterization of Human Fibrocytes as Circulating Adipocyte Progenitors and the Formation of Human Adipose Tissue in SCID Mice. The FASEB Journal, 19, 2029-2031.

[114] Tomiyama, K., Murase, N., Stolz, D.B., et al. (2007) Characterization of Transplanted Green Fluorescent Protein Bone Marrow Cells into Adipose Tissue. Stem Cells, 26, 330-338. http://dx.doi.org/10.1634/stemcells.2007-0567

[115] Sera, Y., LaRue, A.C., Moussa, O., et al. (2009) Hematopoietic Stem Cell Origin of Adipocytes. Experimental Hematology, 37, 1108-1120. http://dx.doi.org/10.1016/j.exphem.2009.06.008

[116] Crossno, J.T., Majka, S.M., Graxia, T., et al. (2006) Rosiglitazone Promotes Development of a Novel Adipocyte Population from Bone Marrow-Derived Circulating Progenitor Cells. Journal of Clinical Investigation, 116, 3220-3229. http://dx.doi.org/10.1172/JCI28510

[117] Hausman, G.J. and Hausman, D.B. (2006) Search for the Preadipocyte Progenitor Cell. Journal of Clinical Investigation, 116, 3103-3107. http://dx.doi.org/10.1172/JCI30666

[118] Billon, N., Jolicoeur, C. and Raff, M. (2006) Generation and Characterization of Oligodendrocytes from Lineage-Selectable Embryonic Stem in Vitro. Methods in Molecular Biology, 330, 15-32.

[119] Takashima, Y., Era, T., Nakao, K., et al. (2007) Neuroepithelial Cells Supply an Initial Transient Wave of MSC Differentiation. Cell, 129, 1377-1388. http://dx.doi.org/10.1016/j.cell.2007.04.028

[120] Billon, N., Iannarelli, P., Monteiro, M.C., et al. (2007) The Generation of Adipocytes by the Neural Crest. Development, 134, 2283-2292. http://dx.doi.org/10.1242/dev.002642

[121] Gregoire, F.M. (2001) Adipocyte Differentiation: From Fibroblast to Endocrine Cell. Experimental Biology and Medicine, 226, 997-1000.

[122] Otto, T.C. and Lane, M.D. (2005) Adipose Development: From Stem Cell to Adipocyte. Critical Reviews in Biochemistry and Molecular Biology, 40, 229-242. http://dx.doi.org/10.1080/10409230591008189

[123] Tang, Q.Q., Otto, T.C. and Lane, M.D. (2004) Commitment of C3H10T1/2 Pluripotent Stem Cells to the Adipocyte Lineage. Proceedings of the National Academy of Sciences of the United States of America, 101, 9607-9611. http://dx.doi.org/10.1073/pnas.0403100101

[124] Aratani, Y. and Kitagawa, Y. (1988) Enhanced Synthesis and Secretion of Type IV Collagen and Entactin during Adi- 
pose Conversion of 373-L1 Cells and Production of Unorthodox Laminin Complex. The Journal of Biological Chemistry, 263, 16161-16169.

[125] Nakajima, I., Yamaguchi, T., Ozutsumi, K., et al. (1998) Adipose Tissue Extracellular Matrix: Newly Organized by Adipocytes during Differentiation. Differentiation, 63, 193-200. http://dx.doi.org/10.1111/j.1432-0436.1998.00193.x

[126] Spiegelman, B.M. and Ginty, C.A. (1983) Fibronectin Modulation of Cell Shape and Lipogenic Gene Expression in 3T3-Adipocytes. Cell, 35, 657-666. http://dx.doi.org/10.1016/0092-8674(83)90098-3

[127] Dike, L.E. and Farmer, S.R. (1988) Cell Adhesion Induces Expression of Growth-Associated Genes in SuspensionArrested Fibroblasts. Proceedings of the National Academy of Sciences of the United States of America, 85, 6792-6796. http://dx.doi.org/10.1073/pnas.85.18.6792

[128] Pairault, J. and Green, H. (1979) A Study of the Adipose Conversion of Suspended 3T3 Cells by Using Glycerophosphate Dehydrogenase as Differentiation Marker. Proceedings of the National Academy of Sciences of the United States of America, 76, 5138-5142. http://dx.doi.org/10.1073/pnas.76.10.5138

[129] Chavey, C., Mari, B., Monthouel, M.-N., et al. (2003) Matrix Metalloproteinases Are Differentially Expressed in Adipose Tissue during Obesity and Modulate Adipocyte Differentiation. The Journal of Biological Chemistry, 278, 1188811896. http://dx.doi.org/10.1074/jbc.M209196200

[130] Christodoulides, C., Lagathu, C., Sethi, J.K., et al. (2009) Adipogenesis and WNT Signalling. Trends in Endocrinology and Metabolism, 20, 16-24. http://dx.doi.org/10.1016/j.tem.2008.09.002

[131] McBreath, R., Pirone, D.M., Nelson, C.M., et al. (2004) Cell Shape, Cytoskeletal Tension, and RhoA Regulate System Cell Lineage Commitment. Developmental Cell, 6, 483-495. http://dx.doi.org/10.1016/S1534-5807(04)00075-9

[132] Zamani, N. and Brown, C.S. (2011) Emerging Roles for the Transforming Growth Factor- $\beta$ Superfamily in Regulating Adiposity and Energy Expenditure. Endocrine Reviews, 32, 387-403. http://dx.doi.org/10.1210/er.2010-0018

[133] Huang, H.Y., Song, T.J., Li, X., et al. (2009) BMP Signaling Pathway Is Required for Commitment of C3H10T1/2 Pluripotent Stem Cells to the Adipocyte Lineage. Proceedings of the National Academy of Sciences of the United States of America, 106, 12670-12675. http://dx.doi.org/10.1073/pnas.0906266106

[134] Kang, Q., Song, W.X., Luo, Q., et al. (2009) A Comprehensive Analysis of the Dual Roles of BMPs in Regulating Adipogenic and Osteogenic Differentiation of Mesenchymal Progenitor Cells. Stem Cells and Development, 18, 545559. http://dx.doi.org/10.1089/scd.2008.0130

[135] Visse, R. and Nagase, H. (2003) Matrix Metalloproteinases and Tissue Inhibitors of Metalloproteinases: Structure, Function, and Biochemistry. Circulation Research, 92, 827-839. http://dx.doi.org/10.1161/01.RES.0000070112.80711.3D

[136] Croissandeau, G., Chretien, M. and Mbikay, M. (2002) Involvement of Matrix Metalloproteinases in the Adipose Conversion of 3T3-L1 Preadipocytes. Biochemical Journal, 364, 739-746. http://dx.doi.org/10.1042/BJ20011158

[137] Mayuoi, E., Munaut, C., Colige, A., et al. (2002) Modulation of Adipose Tissue Expression of Murine Matrix Metalloproteinases and Their Tissue Inhibitors with Obesity. Diabetes, 51, 1093-1101. http://dx.doi.org/10.2337/diabetes.51.4.1093

[138] Ross, S.E., Hemati, N., Longo, K.A., et al. (2000) Inhibition of Adipogenesis by Wnt Signaling. Science, 289, $950-953$. http://dx.doi.org/10.1126/science.289.5481.950

[139] Kikuchi, A., Yamamoto, H. and Kishida, S. (2007) Multiplicity of the Interactions of Wnt Proteins and Their Receptors. Cellular Signalling, 12, 659-671. http://dx.doi.org/10.1016/j.cellsig.2006.11.001

[140] Sen, B., Xie, Z., Case, N., et al. (2008) Mechanical Strain Inhibits Adipogenesis in Mesenchymal Stem Cells by Stimulating a Durable $\beta$-Catenin Signal. Endocrinology, 149, 6065-6075. http://dx.doi.org/10.1210/en.2008-0687

[141] Kawai, M., et al. (2007) Wnt/Lrp/ $\beta$-Catenin Signaling Suppresses Adipogenesis by Inhibiting Mutual Activation of PPAR $\gamma$ and C/EBP $\alpha$. Biochemical and Biophysical Research Communications, 363, 276-282. http://dx.doi.org/10.1016/j.bbrc.2007.08.088

[142] Kikuchi, A., Yamamoto, H. and Sato, A. (2009) Selective Activation Mechanisms of Wnt Signaling Pathways. Trends in Cell Biology, 19, 119-129. http://dx.doi.org/10.1016/j.tcb.2009.01.003

[143] Kang, S., Bennett, C.N., Gerin, I., et al. (2007) Wnt Signaling Stimulates Osteoblastogenesis of Mesenchymal Precursors by Suppressing CCAAT Enhancer-Binding Proteins $\alpha$ and Peroxisome Proliferator-Activated Receptor $\gamma$. The Journal of Biological Chemistry, 282, 14515-14524. http://dx.doi.org/10.1074/jbc.M700030200

[144] Kanazawa, A., et al. (2005) Wnt5b Partially Inhibits Canonical Wnt- $\beta$ Catenin Signaling Pathway and Promotes Adipogensis in 3T3-L1 Preadipocytes. Biochemical and Biophysical Research Communications, 330, 505-510. http://dx.doi.org/10.1016/j.bbrc.2005.03.007

[145] Liu, J., DeYoung, S.M., Zhang, M., et al. (2005) Changes in Integrin Expression during Adipocyte Differentiation. Cell Metabolism, 2, 165-177. http://dx.doi.org/10.1016/j.cmet.2005.08.006 
[146] Killian, I.A., Bugarija, B., Lahn, B.T., et al. (2010) Geometric Cues for Directing the Differentiation of Mesenchymal Stem Cells. Proceedings of the National Academy of Sciences of the United States of America, 107, 4872-4877. http://dx.doi.org/10.1073/pnas.0903269107

[147] Dupont, S., et al. (2011) Role of YAP/TAZ in Mechanotransduction. Nature, 474, 179-183. http://dx.doi.org/10.1038/nature10137

[148] Kingsley, D.M. (1994) The TGF- $\beta$ Superfamily: New Members, New Receptors, and New Genetic Tests of Function in Different Organisms. Genes \& Development, 8, 133-146. http://dx.doi.org/10.1101/gad.8.2.133

[149] Derynck, R. and Miiyazono, K.O. (2007) The TGF- $\beta$ Family. Cold Spring Harbor Laboratory Press, Cold Spring Harbor.

[150] Schultz, T.J. and Tseng, Y.H. (2009) Emerging Role of Bone Morphogenetic Proteins in Adipogenesis and Energy Metabolism. Cytokine \& Growth Factor Reviews, 20, 523-531. http://dx.doi.org/10.1016/j.cytogfr.2009.10.019

[151] Wrana, J.L., Attisano, L., Wieser, R., et al. (1994) Mechanism of Activation of the TGF- $\beta$ Receptor. Nature, 370, 341347. http://dx.doi.org/10.1038/370341a0

[152] Chang, H., Brown, C.W. and Matzuk, M.M. (2002) Genetic Analysis of Mammalian Transforming Growth Factor- $\beta$ Superfamily. Endocrine Reviews, 23, 787-823. http://dx.doi.org/10.1210/er.2002-0003

[153] Hill, C.S. (2009) Nucleocytoplasmic Shuttling of Smad Proteins. Cell Research, 19, 36-46. http://dx.doi.org/10.1038/cr.2008.325

[154] Varelas, X., Sakuma, R., Samavarichi-Tehrani, P., et al. (2008) TAZ Controls Smad Nucleocytoplasmic Shuttling and Regulates Human Embryonic Stem-Cell Self-Renewal. Nature Cell Biology, 10, 837-848. http://dx.doi.org/10.1038/ncb1748

[155] Choy, L., Skillington, J. and Derynck, R. (2000) Roles of Autocrine TGF- $\beta$ Receptor and Smad Signaling in Adipocyte Differentiation. The Journal of Cell Biology, 149, 667-682. http://dx.doi.org/10.1083/jcb.149.3.667

[156] Choy, L. and Derynck, R. (2003) Transforming Growth Factor- $\beta$ Inhibits Adipocyte Differentiation by Smad3 Interacting with CCAAT/Enhancer-Binding Protein (C/EBP) and Repressing C/EBP Transactivation Function. The Journal of Biological Chemistry, 278, 9609-9619. http://dx.doi.org/10.1074/jbc.M212259200

[157] Zhou, S., Eid, K. and Glowacki, J. (2004) Cooperation between TGF- $\beta$ and Wnt Pathways during Chondrocyte and Adipocyte Differentiation of Human Marrow Stromal Cells. Journal of Bone and Mineral Research, 19, 463-470. http://dx.doi.org/10.1359/JBMR.0301239

[158] Hirota, M., Watanabe, K., Hamada, S., et al. (2008) Smad2 Functions as a Co-Activator of Canonical Wnt/ $\beta$-Catenin Signaling Pathway Independent of Smad4 through Histone Acetyltranferase Activity of p300. Cellular Signalling, 20, 1632-1641. http://dx.doi.org/10.1016/j.cellsig.2008.05.003

[159] Jeoung, D.I., Tang, B. and Sonenberg, M. (1995) Mitogenic Response to TGF- $\beta$ in 3T3-F442A Cells. Biochemical and Biophysical Research Communications, 216, 964-969. http://dx.doi.org/10.1006/bbrc.1995.2714

[160] Zaragosi, L.E., Wdziekonski, B., Villageois, P., et al. (2010) Activin A Plays a Critical Role in Proliferation and Differentiation of Human Progenitors. Diabetes, 59, 2513-2521. http://dx.doi.org/10.2337/db10-0013

[161] Huang, H.Y., Song, T.J., Li, X., et al. (2009) BMP Signaling Pathway Is Required for Commitment of C3H10T1/2 Pluripotent Stem Cells to the Adipocyte Lineage. Proceedings of the National Academy of Sciences of the United States of America, 106, 12670-12675. http://dx.doi.org/10.1073/pnas.0906266106

[162] Bowers, R.R., Kim, J.W., Otto, T.C., et al. (2006) Stable Stem Cell Commitment to the Adipocyte Lineage by Inhibition of DNA Methylation: Role of the BMP-4 Gene. Proceedings of the National Academy of Sciences of the United States of America, 103, 10322-13027. http://dx.doi.org/10.1073/pnas.0605789103

[163] Bowers, R.R. and Lane, M.D. (2007) A Role for Bone Morphogenetic Protein-4 in Adipocyte Development. Cell Cycle, 6, 385-389. http://dx.doi.org/10.4161/cc.6.4.3804

[164] Taha, M.F., Valojerdi, M.R. and Mowla, S.J. (2006) Effect of Bone Morphogenetic Protein-4 (BMP-4) on Adipocyte Differentiation from Mouse Embryonic Stem Cells. Anatomia, Histologia, Embryologia, 35, 271-278. http://dx.doi.org/10.1111/j.1439-0264.2006.00680.x

[165] Huang, H.Y., Hu, L.L., Song, T.J., et al. (2011) Involvement of Cytoskeleton-Associated Proteins in the Commitment of C3H10T1/2 Pluripotent Stem Cells to Adipocyte Lineage Induced by BMP2/4. Molecular \& Cellular Proteomics, 10, Article ID: M110.002691. http://dx.doi.org/10.1074/mcp.M110.002691

[166] Tseng, Y.H., Kokkotou, E., Schulz, T.J., et al. (2008) New Role of Bone Morphogenetic Protein 7 in Brown Adipogenesis and Energy Expenditure. Nature, 454, 1000-1004. http://dx.doi.org/10.1038/nature07221

[167] Seale, P., Bjork, B., Yang, W., et al. (2008) PRDM16 Controls in Brown Fat/Skeletal Muscle Switch. Nature, 454, 961-967. http://dx.doi.org/10.1038/nature07182 
[168] Tang, Q.-Q. and Lane, M.D. (1999) Activation and Centromeric Localization of CCAAT/Enhancer Binding-Proteins during the Mitotic Clonal Expansion of Adipocyte Differentiation. Genes \& Development, 13, 2231-2241. http://dx.doi.org/10.1101/gad.13.17.2231

[169] Tang, Q.-Q., Otto, T.C. and Lane, M.D. (2003) Mitotic Clonal Expansion: Asynchronous Process Required for Adipogenesis. Proceedings of the National Academy of Sciences of the United States of America, 100, 44-49. http://dx.doi.org/10.1073/pnas.0137044100

[170] Zhu, Y., Qi, C., Korenbery, J.R., et al. (1995) Structural Organization of Mouse Peroxisome Proliferator-Activated Receptor $\gamma(\mathrm{mPPAR} \gamma)$ Gene: Alternative Promoter Use and Different Splicing Yield Two mPPAR $\gamma$ Isoforms. Proceedings of the National Academy of Sciences of the United States of America, 92, 7921-7925. http://dx.doi.org/10.1073/pnas.92.17.7921

[171] Fajas, L., Auboeuf, E., Raspe, K., et al. (1997) The Organization, Promoter Analysis, and Expression of the Human PPAR $\gamma$ Gene. The Journal of Biological Chemistry, 272, 18779-18789. http://dx.doi.org/10.1074/jbc.272.30.18779

[172] Wu, Z., Rosen, E.D., Brun, R., et al. (1999) Cross-Regulation of C/EBP $\alpha$ and PPAR $\gamma$ Controls the Transcriptional Pathway of Adipogenesis and Insulin Sensitivity. Molecular Cell, 3, 151-158. http://dx.doi.org/10.1016/S1097-2765(00)80306-8

[173] Elberg, G., Gimble, J.M. and Tsai, S.Y. (2000) Modulation of the Murine Peroxisome Proliferator-Activated Receptor Gamma 2 Promoter Activity by CCAAT/Enhancer-Binding Proteins. The Journal of Biological Chemistry, 275, 27815-27822.

[174] Fajas, L., Schoonjans, K., Gelman, L., et al. (1999) Regulation of Peroxisome Proliferator-Activated Receptor $\gamma$ Expression by Adipocyte Differentiation and Determination Factor1/Sterol Regulatory Element Binding Protein 1: Implications for Adipocyte Differentiation and Metabolism. Molecular and Cellular Biology, 19, 5495-5503.

[175] Kawai, M. and Rosen, C.J. (2010) PPAR $\gamma$, a Circadian Transcription Factor in Adipogenesis and Osteogenesis. Nature Reviews Endocrinology, 6, 629-636.

[176] Wang, J. and Lazar, M.A. (2008) Bifunctional Role of Rev-erb $\alpha$ in Adipocyte Differentiation. Molecular and Cellular Biology, 28, 2213-2220.

[177] Kawai, M., et al. (2010) A Circadian-Regulated Gene, Nocturnin, Promotes Adipogenesis by Stimulating PPAR- $\gamma$ Nuclear Translocation. Proceedings of the National Academy of Sciences of the United States of America, 107, 1050810513. http://dx.doi.org/10.1073/pnas.1000788107

[178] Villanueva, C.J., et al. (2011) TLE3 Is a Dual-Function Transcriptional Coregulator of Adipogenesis. Cell Metabolism, 13, 413-427. http://dx.doi.org/10.1016/j.cmet.2011.02.014

[179] Tong, Q., et al. (2000) Function of GATA Transcription Factors in Preadipocytes-Adipocyte Transition. Science, 290, 134-138. http://dx.doi.org/10.1126/science.290.5489.134

[180] Rangwala, S.M. and Laza, M.A. (2004) Peroxisome Proliferator-Activated Receptor $\gamma$ in Diabetes and Metabolism. Trends in Pharmacological Sciences, 25, 331-336. http://dx.doi.org/10.1016/j.tips.2004.03.012

[181] Muller-Eberhard, H.J. and Schreiber, R.D. (1980) Molecular Biology and Chemistry of the Alternative Pathway of Complement. Advances in Immunology, 29, 1-53. http://dx.doi.org/10.1016/S0065-2776(08)60042-5

[182] Hu, E., Liang, P. and Spiegelman, B.M. (1996) AdipoQ Is a Novel Adipose-Specific Gene Dysregulated in Obesity. The Journal of Biological Chemistry, 271, 10697-10703. http://dx.doi.org/10.1074/jbc.271.18.10697

[183] Klein, S., Coppack, S.E., Mohamed-Ali, V., et al. (1996) Adipose Tissue Leptin Production and Plasma Leptin Kinetics in Humans. Diabetes, 45, 984-987. http://dx.doi.org/10.2337/diab.45.7.984

[184] Steppan, C.M., Bailey, S.T., Bhat, S., et al. (2001) The Hormone Resistin Links Obesity to Diabetes. Nature, 409, 307312. http://dx.doi.org/10.1038/35053000

[185] Lefterova, M., Zhang, Y., Steger, D.J., et al. (2008) PPAR $\gamma$ and C/EBP Factors Orchestrate Adipocyte Biology via Adjacent Binding on a Genome-Wide Scale. Genes \& Development, 22, 2941-2952. http://dx.doi.org/10.1101/gad.1709008

[186] Mikkelsen, R.S., Xu, Z., Zhang, X., et al. (2010) Comparative Epigenomic Analysis of Murine and Human Adipogenesis. Cell, 143, 156-169. http://dx.doi.org/10.1016/j.cell.2010.09.006

[187] Tang, Q.Q., Zhang, J.W. and Lane, D. (2004) Sequential Gene Promoter Interactions of C/EBP $\beta, \operatorname{C/EBP} \alpha$ and PPAR $\gamma$ during Adipogenesis. Biochemical and Biophysical Research Communications, 319, 235-239. http://dx.doi.org/10.1016/j.bbrc.2004.04.176

[188] West, A.G. and Fraser, P. (2005) Remote Control of Gene Transcription. Human Molecular Genetics, 14, R101-R111. http://dx.doi.org/10.1093/hmg/ddi104

[189] Schupp, M., Cristancho, A.G., Lefterova, M.I., et al. (2009) Re-Expression of GATA2 Cooperates with Peroxisome Proliferator-Activated Receptor- $\gamma$ Depletion to Revert the Adiopcyte Phenotype. The Journal of Biological Chemistry, 
284, 9458-9464. http://dx.doi.org/10.1074/jbc.M809498200

[190] Liao, W., Nyuyen, M.T., Yoshizaki, T., et al. (2007) Suppression of PPAR- $\gamma$ Attenuates Insulin-Stimulated Glucose Uptake by Affecting Both GLUTI and GLUT4 in 3T3-L1 Adipocytes. The American Journal of Physiology: Endocrinology and Metabolism, 293, e219-e227. http://dx.doi.org/10.1152/ajpendo.00695.2006

[191] Imai, T., Takakuwa, R., Marchand, S., et al. (2004) Peroxisome Proliferator-Activated Receptor $\gamma$ Is Required in Mature White and Brown Adipocytes for Their Survival in the Mouse. Proceedings of the National Academy of Sciences of the United States of America, 101, 4543-4547. http://dx.doi.org/10.1073/pnas.0400356101

[192] Kirtland, J. and Harris, P.M. (1980) Changes in Adipose Tissue of the Rat Due to Early Undernutrition Followed by Rehabilitation. 3. Changes in Cell Replication Studied with Tritiated Thymidhe. British Journal of Nutrition, 43, 33-43. http://dx.doi.org/10.1079/BJN19800062

[193] Ibrahim, M.M. (2010) Subcutaneous and Visceral Adipose Tissue: Structural and Functional Differences. Obesity Reviews, 11, 11-18. http://dx.doi.org/10.1111/j.1467-789X.2009.00623.x

[194] Girard, J. and Lafontan, M. (2008) Impact of Visceral Adipose Tissue on Liver Metabolism and Insulin Resistance. Part II: Visceral Adipose Tissue Production and Liver Metabolism. Diabetes \& Metabolism, 34, 439-445. http://dx.doi.org/10.1016/j.diabet.2008.04.002

[195] Perrini, S., Laviola, L., Cignarelli, A., et al. (2008) Fat Depot-Related Differences in Gene Expression, Adiponectin Secretion, and Insulin Action and Signaling in Human Adipocytes Differentiated in Vitro from Precursor Stromal Cells. Diabetologia, 51, 155-164. http://dx.doi.org/10.1007/s00125-007-0841-7

[196] Trayhurn, P. and Beattie, J.H. (2001) Physiological Role of Adipose Tissue: White Adipose Tissue as an Endocrine and Secretory Organ. Proceedings of the Nutrition Society, 60, 329-339. http://dx.doi.org/10.1079/PNS200194

[197] Frontini, A. and Cinti, S. (2010) Distribution and Development of Brown Adipocytes in the Murine and Human Adipose Organ. Cell Metabolism, 11, 253-256. http://dx.doi.org/10.1016/j.cmet.2010.03.004

[198] Peschehera, A. and Eckel, J. (2013) "Browning” of Adipose Tissue-Regulation and Therapeutic Perspectives. Archives of Physiology and Biochemistry, 119, 151-160. http://dx.doi.org/10.3109/13813455.2013.796995

[199] Cannon, B. and Nedergaard, J. (2004) Brown Adipose Tissue: Function and Physiological Significance. Physiological Reviews, 84, 277-359. http://dx.doi.org/10.1152/physrev.00015.2003

[200] Cannon, B. and Nedergaard, J. (2010) Metabolic Consequences of the Presence or Absence of the Thermogenic Capacity of Brown Adipose Tissue in Mice (and Probably in Humans). International Journal of Obesity, 34, S7-S16. http://dx.doi.org/10.1038/ijo.2010.177

[201] Timmons, J.A., Wennmalm, K., Larsson, O., et al. (2007) Myogenic Gene Expression Signature Establishes That Brown and White Adipocytes Originate from Distinct Cell Lineages. Proceedings of the National Academy of Sciences of the United States of America, 104, 4401-4406. http://dx.doi.org/10.1073/pnas.0610615104

[202] Seale, P., Kajimura, S., Yang, W., et al. (2008) PRDM16 Controls a Brown Fat/Skeletal Muscle Switch. Nature, 454, 961-967. http://dx.doi.org/10.1038/nature07182

[203] Lepper, C. and Fan, C.M. (2010) Inducible Lineage Tracing of Pax7-Descendant Cells Reveals Embryonic Origin of Adult Satellite Cells. Genesis, 48, 424-436. http://dx.doi.org/10.1002/dvg.20630

[204] Petrovic, N., Walden, T.B., Shabalina, I.G., et al. (2010) Chronic Peroxisome Proliferator-Activated Receptor $\gamma$ $(\operatorname{PPAR} \gamma)$ Activation of Epididymally Derived White Adipocyte Cultures Reveals a Population of Themogenially Competent, UCP1-Containing Adipocytes Molecularly Distinct from Classic Brown Adipocytes. The Journal of Biological Chemistry, 285, 7153-7164. http://dx.doi.org/10.1074/jbc.M109.053942

[205] Wu, J., Bostrom, P., Sparks, L.M., et al. (2012) Beige Adipocytes Are Distinct Type of Thermogenic Fat Cell in Mouse and Human. Cell, 150, 366-376. http://dx.doi.org/10.1016/j.cell.2012.05.016

[206] Cinti, S. (2009) Transdifferentiation Properties of Adipocytes in the Adipose Organ. The American Journal of Physiology: Endocrinology and Metabolism, 297, E977-E986. http://dx.doi.org/10.1152/ajpendo.00183.2009

[207] Elabd, C., Chiellini, C., Carmona, M., et al. (2009) Human Multipotent Adipose-Derived Stem Cells Differentiate into Functional Brown Adipocytes. Stem Cells, 27, 2753-2760. http://dx.doi.org/10.1002/stem.200

[208] Di Girolamo, M. and Fine, J.D. (2000) Obesity. In: Branch Jr., W.T., Alexander, R.W., Schlant, R.C. and Hurst, J., Eds., Cardiology in Primary Care, McGraw-Hill, New York, 265-278.

[209] Hausman, D.B., DiGirolamo, M., Bartness, T.J., et al. (2001) The Biology of White Adipocyte Proliferation. Obesity Reviews, 2, 239-254. http://dx.doi.org/10.1046/j.1467-789X.2001.00042.x

[210] Green, H. and Meuth, M. (1974) An Established Pre-Adipose Cell Line and Its Differentiation in Culture. Cell, 3, 127133. http://dx.doi.org/10.1016/0092-8674(74)90116-0

[211] Neese, R.A., Misell, L.M., Turner, S., et al. (2002) Measurement in Vivo of Proliferation Rates of Slow Turnover Cells 
by ${ }^{2} \mathrm{H}_{2} \mathrm{O}$ Labeling of the Deoxyribose Moiety of DNA. Proceedings of the National Academy of Sciences of the United States of America, 99, 15345-15350. http://dx.doi.org/10.1073/pnas.232551499

[212] Strawford, A., Antelo, F., Christiansen, M., et al. (2004) Adipose Tissue Triglyceride Turnover, de Novo Lipogenesis, and Cell Proliferation in Humans Measured with ${ }^{2} \mathrm{H}_{2} \mathrm{O}$. The American Journal of Physiology: Endocrinology and Metabolism, 286, E577-E588. http://dx.doi.org/10.1152/ajpendo.00093.2003

[213] Prins, H.B. and O’Rahilly, S. (1997) Regulation of Adipose Cell Number in Man. Clinical Science, 92, 3-11.

[214] Knittle, J.L., Timmers, K., Ginsberg-Fellner, F., et al. (1979) The Growth of Adipose Tissue in Children and Adolescence. Cross-Sectional and Longitudinal Studies of Adipose Cell Number and Size. Journal of Clinical Investigation, 63, 239-246. http://dx.doi.org/10.1172/JCI109295

[215] Spalding, K.L., Arner, E., Westermark, P.O., et al. (2008) Dynamics of Fat Cell Turnover in Humans. Nature, 453, 783-786. http://dx.doi.org/10.1038/nature06902

[216] Tchoukalova, Y.D., Votruba, S.B., Tchkonia, T., et al. (2010) Regional Differences in Cellular Mechanisms of Adipose Tissue Gain with Overfeeding. Proceedings of the National Academy of Sciences of the United States of America, 107, 18226-18231. http://dx.doi.org/10.1073/pnas.1005259107

[217] Tchoukalova, Y., Koutsari, C. and Jensen, M.D. (2007) Committed Subcutaneous Preadipocytes Are Reduced Inhuman Obesity. Diabetologia, 50, 151-157. http://dx.doi.org/10.1007/s00125-006-0496-9

[218] Tholpady, S.S., Llull, R., Ogle, R.C., et al. (2006) Adipose Tissue: Stem Cells and Beyond. Clinics in Plastic Surgery, 33, 55-62. http://dx.doi.org/10.1016/j.cps.2005.08.004

[219] Eto, H., Suga, H., Matsumoto, D., et al. (2009) Characterization of Structure and Cellular Components of Aspirated and Excised Adipose Tissue. Plastic and Reconstructive Surgery, 124, 1087-1097. http://dx.doi.org/10.1097/PRS.0b013e3181b5a3f1

[220] Nakajima, I., Muroya, S., Tanabe, R., et al. (2002) Extracellular Matrix Development during Differentiation into Adipocytes with a Unique Increase in Type V and VI Collagen. Biology of the Cell, 94, 197-203. http://dx.doi.org/10.1016/S0248-4900(02)01189-9

[221] Sugihara, H., Yonemitsu, N., Miyabara, S., et al. (1987) Proliferation of Unilocular Fat Cell in the Primary Culture. The Journal of Lipid Research, 28, 1038-1045.

[222] Suga, H., Matsumoto, D., Inoue, K., et al. (2008) Numerical Measurement of Viable and Nonviable Adipocytes and Other Cellular Components in Aspirated Fat Tissue. Plastic and Reconstructive Surgery, 122, 103-114. http://dx.doi.org/10.1097/PRS.0b013e31817742ed

[223] Van Harmelen, V., Skurk, T. and Hauner, H. (2005) Primary Culture and Differentiation of Human Adipocyte Recursor Cells. Methods in Molecular Medicine, 107, 125-135.

[224] Kubik, S. and Kretz, O. (2006) Initial Lymph Vascular System of Various Tissues and Organs. In: Foldi, M., et al., Eds., Foldi's Textbook of Lymphology, Elsivier GmbH, Munich, 24-41.

[225] Crandall, D.L., Hausman, G.J. and Kral, J.G. (1997) A Review of the Microcirculation of Adipose Tissue: Anatomic, Metabolic, and Angiogenic Perspectives. Microcirculation, 4, 221-232. http://dx.doi.org/10.3109/10739689709146786

[226] Gir, P., Brown, S.A., Oni, G., et al. (2012) Fat Grafting: Evidence-Based Review on Autologous Fat Harvesting, Processing, Reinjection, and Storage. Plastic and Reconstructive Surgery, 130, 249-258. http://dx.doi.org/10.1097/prs.0b013e318254b4d3

[227] Gimble, J.M., Bunnell, B.A., Chiu, E.S., et al. (2011) Concise Review: Adipose-Derived Stromal Vascular Fraction Cells and Stem Cells: Let's Not Get Lost in Translation. Stem Cells, 29, 749-754. http://dx.doi.org/10.1002/stem.629

[228] Zhu, X., Shi, W., Tai, W., et al. (2012) The Comparition of Biological Characteristics and Multilineage Differentiation of Bone Marrow and Adipose Derived Mesenchymal Stem Cells. Cell and Tissue Research, 350, 277-287. http://dx.doi.org/10.1007/s00441-012-1453-1

[229] Gimble, J.M., Katz, A.J. and Bunnell, B.A. (2007) Adipose-Derived Stem Cells for Regenerative Medicine. Circulation Research, 100, 1249-1260. http://dx.doi.org/10.1161/01.RES.0000265074.83288.09

[230] Rodbell, M. (1964) Metabolism of Isolated Fat Cells. I. Effects of Hormones on Glucose Metabolism and Lipolysis. The Journal of Biological Chemistry, 239, 375-380.

[231] Rodbell, M. and Jones, A.B. (1966) Metabolism of Isolated Fat Cells. 3. The Similar Inhibitory Action of Phospholipase C (Clostridium Perfringens Alpha Toxin) and of Insulin on Lipolysis Stimulated by Lipolytic Hormones and Theophylline. The Journal of Biological Chemistry, 241, 140-142.

[232] Van, R.L., Baylliss, C.E. and Roncari, D.A. (1976) Cytological and Enzymological Characterization of Adult Human Adipocyte Precursors in Culture. Journal of Clinical Investigation, 58, 699-704. http://dx.doi.org/10.1172/JCI108516

[233] Hauner, H., Entenmann, G., Wabitsch, M., Gaillard, D., et al. (1989) Promoting Effect of Glucocorticoids on the Dif- 
ferentiation of Human Adipocyte Precursor Cells Cultured in a Chemically Defined Medium. Journal of Clinical Investigation, 84, 1663-1670. http://dx.doi.org/10.1172/JCI114345

[234] Moore Jr., J.H., Kolaczynski, J.W., Morales, L.M., et al. (1995) Viability of Fat Obtained by Syringe Suction Lipectomy: Effects of Local Anesthesia with Lidocaine. Aesthetic Plastic Surgery, 19, 335-339. http://dx.doi.org/10.1007/BF00451659

[235] Lalikos, J.F., Li, Y.Q., Roth, T.P., et al. (1997) Biochemical Assessment of Cellular Damage after Adipocyte Harvest. Journal of Surgical Research, 70, 95-100. http://dx.doi.org/10.1006/jsre.1997.5090

[236] Oedayrajsingh-Varma, M.J., Van Ham, S.M., Knippenberg, M., et al. (2006) Adipose Tissue-Derived Mesenchymal Stem Cell Yield and Growth Characteristics Are Affected by the Tissue-Harvesting Procedure. Cytotherapy, 8, 166177. http://dx.doi.org/10.1080/14653240600621125

[237] Yoshimura, K., Shigeura, T., Matsumoto, D., et al. (2006) Characterization of Freshly Isolated and Cultured Cells Derived from the Fatty and Fluid Portions of Liposuction Aspirates. Journal of Cellular Physiology, 208, 64-76. http://dx.doi.org/10.1002/jcp.20636

[238] Shah, F.S., Wu, X., Dietrich, M., et al. (2013) A Non-Enzymatic Method for Isolating Adipose Tissue-Derived Stromal Stem Cells. Cytotherapy, 15, 979-985. http://dx.doi.org/10.1016/j.jcyt.2013.04.001

[239] Francis, M.P., Sachs, P.C., Elmore, L.W., et al. (2010) Isolating Adipose-Derived Mesenchymal Stem Cells from Lipoaspirate Blood and Saline Fraction. Organogenesis, 6, 11-14. http://dx.doi.org/10.4161/org.6.1.10019

[240] Zuk, P.A., Zhu, M., Ashjian, P., et al. (2002) Human Adipose Tissue Is a Source of Multipotent Stem Cells. Molecular Biology of the Cell, 13, 4279-4295. http://dx.doi.org/10.1091/mbc.E02-02-0105

[241] Yoshimura, K., Suga, H. and Eto, H. (2009) Adipose-Derived Stem/Progenitor Cells: Roles in Adipose Tissue Remodeling and Potential Use for Soft Tissue Augmentation. Regenerative Medicine, 4, 265-273. http://dx.doi.org/10.2217/17460751.4.2.265

[242] Maumus, M., Peyrafitte, J.A., D’Angelo, R., et al. (2011) Native Human Adipose Stromal Cells: Localization, Morphology and Phenotype. International Journal of Obesity, 35, 1141-1153. http://dx.doi.org/10.1038/ijo.2010.269

[243] Boquest, A.C., Shahdadfar, A., Fronsdal, K., et al. (2005) Isolation and Transcription Profiling of Purified Uncultured Human Stromal Stem Cells: Alteration of Gene Expression after in Vitro Cell Culture. Molecular Biology of the Cell, 16, 1131-1141. http://dx.doi.org/10.1091/mbc.E04-10-0949

[244] Szoke, K., Beckstrom, K.J. and Brinchmann, H.E. (2012) Human Adipose Tissue as a Source of Cells with Angiogenic Potential. Cell Transplantation, 21, 235-250. http://dx.doi.org/10.3727/096368911X580518

[245] Zuk, P.A., Zhu, M., Mizuno, H., et al. (2001) Multilineage Cells from Human Adipose Tissue: Implications for CellBased Therapies. Tissue Engineering, 7, 211-228. http://dx.doi.org/10.1089/107632701300062859

[246] McIntoch, K., Zvonic, S., Garrett, S., et al. (2006) The Immunogenicity of Human Adipose Derived Cells Temporal Changes in Vitro. Stem Cells, 24, 1246-1253.

[247] Mitchell, J.B., McIntosh, K., Zvonic, S., et al. (2006) The Immunophenotype of Human Adipose Derived Cells: Temporal Changes in Stromal- and Stem Cell-Associated Markers. Stem Cells, 24, 376-385. http://dx.doi.org/10.1634/stemcells.2005-0234

[248] Gronthos, S., Franklin, D.M., Leddy, H.A., et al. (2001) Surface Protein Characterization of Human Adipose-Derived Stromal Cells. Journal of Cellular Physiology, 189, 54-63. http://dx.doi.org/10.1002/jcp.1138

[249] Pachon-Pena, B., Yu, G., Tucker, A., et al. (2007) Stromal Stem Cells from Adipose Tissue and Bone Marrow of AgeMatched Female Donors Display Distinct Immunophenotypic Profiles. Journal of Cellular Physiology, 212, 702-709.

[250] Yanez, R., Lamana, M.L., Garcia-Castro, J., Colmenero, I., et al. (2006) Adipose Tissue-Derived Mesenchymal Stem Cells Have in Vivo Immunosuppressive Properties Applicable for the Control of the Graft-versus-Host Disease. Stem Cells, 24, 2582-2591. http://dx.doi.org/10.1634/stemcells.2006-0228

[251] Kilroy, G.E., Foster, S., Wu, X., et al. (2007) Cytokine Profile of Human Adipose-Derived Stem Cells: Expression of Angiogenic, Hematopoietic, and Pro-Inflammatory Factors. Journal of Cellular Physiology, 212, 702-709. http://dx.doi.org/10.1002/jcp.21068

[252] Gimble, J.M., Guilak, F., Bunnell, B.A. (2010) Clinical and Preclinical Translation of Cell-Base Therapies Using Adipose Tissue-Derived Cells. Stem Cell Research \& Therapy, 1, 19. http://dx.doi.org/10.1186/scrt19

[253] Puissant, B., Barreau, C., Bourin, P., et al. (2005) Immunomodulatory Effect of Human Adipose Tissue-Derived Adult Stem Cells; Comparison with Bone Marrow Mesenchymal Stem Cells. British Journal of Haematology, 129, 118-129. http://dx.doi.org/10.1111/j.1365-2141.2005.05409.x

[254] Yanez, R., Oviedo, A., Aldea, M., et al. (2010) Prostaglandin $E_{2}$ Plays a Key Role in the Immunosuppressive Properties of Adipose and Bone Marrow Tissue-Derived Mesenchymal Stromal Cells. Experimental Cell Research, 316, 3109-3123. http://dx.doi.org/10.1016/j.yexcr.2010.08.008 
[255] Choi, J.H., Gimble, J.M., Lee, K., et al. (2010) Adipose Tissue Engineering for Soft Tissue Regeneration. Tissue Engineering Part B: Reviews, 16, 413-426. http://dx.doi.org/10.1089/ten.teb.2009.0544

[256] L’Heureux, N., Paquet, S., Labbe, R., el al. (1998) A Completely Biological Tissue-Engineered Human Blood Vessel. The FASEB Journal, 12, 47-56.

[257] L’Heureux, N., Dusserre, N., Konig, G., et al. (2006) Human Tissue-Engineered Blood Vessels for Adult Arterial Revascularization. Nature Medicine, 12, 361-365. http://dx.doi.org/10.1038/nm1364

[258] Langer, R. and Vacanti, J.P. (1993) Tissue Engineering. Science, 260, 920-926. http://dx.doi.org/10.1126/science.8493529

[259] Mauney, J.R., Nguyen, T., Gillen, K., et al. (2007) Engineering Adipose-Like Tissue in Vitro and in Vivo Utilizing Human Bone Marrow and Adipose-Derived Mesenchymal Stem Cells with Silk Fibroin 3D Scaffolds. Biomaterials, 28, 5280-5290. http://dx.doi.org/10.1016/j.biomaterials.2007.08.017

[260] Wong, V.W., Rustad, K.C., Longaker, M.T., et al. (2010) Tissue Engineering in Plastic Surgery: A Review. Plastic and Reconstructive Surgery, 126, 858-868. http://dx.doi.org/10.1097/PRS.0b013e3181e3b3a3

[261] Kang, J.H., Gimble, J.M. and Kaplan, D.L. (2009) In Vitro 3D Model for Human Vascularized Adipose Tissue. Tissue Engineering Part A, 15, 2227-2236. http://dx.doi.org/10.1089/ten.tea.2008.0469

[262] Eremia, S. and Newman, N. (2000) Long-Term Follow-Up after Autologous Fat Grating: Analysis of Results from116 Patients Followed at Least 12 Months after Receiving the Last of a Minimum of Two Treatments. Dermatologic Surgery, 26, 1150-1158. http://dx.doi.org/10.1046/j.1524-4725.2000.00277.x

[263] Matsumoto, D., Sato, K., Gonda, K., et al. (2006) Cell-Assisted Lipotransfer: Supportive Use of Human Adipose-Derived Cells for Soft Tissue Augmentation with Lipoinjection. Tissue Engineering, 12, 3375-3382. http://dx.doi.org/10.1089/ten.2006.12.3375

[264] Yoshimura, K., Sato, K., Aoi, N., et al. (2008) Cell-Assisted Lipotrasfer for Facial Lipoatrophy: Efficacy of Clinical Use of Adipose-Derived Stem Cells. Dermatologic Surgery, 34, 1178-1185.

[265] Mojallal, A., Shipkov, C., Braye, F., et al. (2009) Influence of the Recipient Site on the Outcomes of Fat Grafting in Facial Reconstructive Surgery. Plastic and Reconstructive Surgery, 124, 471-483. http://dx.doi.org/10.1097/PRS.0b013e3181af023a

[266] Yoshimura, K., Asano, Y., Aoi, N., et al. (2010) Progenitor-Enriched Adipose Tissue Transplantation as Rescue for Breast Implant Complications. The Breast Journal, 16, 169-175. http://dx.doi.org/10.1111/j.1524-4741.2009.00873.x

[267] Beeson, W., Woods, E. and Agha, R. (2011) Tissue Engineering, Regenerative Medicine, and Rejuvenation in 2010: The Role of Adipose-Derived Stem Cells. Facial Plastic Surgery, 27, 378-387. http://dx.doi.org/10.1055/s-0031-1283056

[268] Rigotti, G., Marchi, A., Galie, M., et al. (2007) Clinical Treatment of Radiotherapy Tissue Damage by Lipoaspirate Transplant: A Healing Process Mediated by Adipose-Derived Adult Stem Cells. Plastic and Reconstructive Surgery, 119, 1409-1422, Discussion 1423-1424. http://dx.doi.org/10.1097/01.prs.0000256047.47909.71

[269] Lendeckel, S., Jodicke, A., Christophis, P., et al. (2004) Autologous Stem Cells (Adipose) and Fibrin Glue Used to Treat Widespread Traumatic Calvarial Defects: Case Report. Journal of Cranio-Maxillofacial Surgery, 32, 370-373. http://dx.doi.org/10.1016/j.jcms.2004.06.002

[270] Sun, F., Zhou, K., Mi, W.J. and Qiu, J.H. (2011) Combined Use of Decellularized Allogeneic Artery Conduits with Autologous Transdifferentiated Adipose-Derived Stem Cells for Facial Nerve Regeneration in Rats. Biomaterials, 32, 8118-8128.

[271] Zografou, A., Tsigris, C., Papadopoulos, O., et al. (2001) Improvement of Skin-Graft Survival after Autologous Transplantation of Adipose-Derived Stem Cells in Rats. Journal of Plastic, Reconstructive \& Aesthetic Surgery, 64, 16471656. http://dx.doi.org/10.1016/j.bjps.2011.07.009

[272] Shi, C.Z., Zhang, X.P., Lv, S.W., et al. (2012) Adipose Tissue-Derived Stem Cells Embedded with eNOS Restore Cardiac Function in Acute Myocardial Infarction Model. International Journal of Cardiology, 154, 2-8. http://dx.doi.org/10.1016/j.ijcard.2011.05.078

[273] Pak, J. (2011) Regeneration of Human Bones in Hip Osteonecrosis and Human Cartilage in Knee Osteoarthritis with Autologous Adipose-Tissue-Derived Stem Cells: A Case Series. Journal of Medical Case Reports, 5, 296. http://dx.doi.org/10.1186/1752-1947-5-296

[274] von Tigerstrom, B. (2009) Product Regulation and the Clinical Translation of Stem Cell Research. Stem Cell Reviews and Reports, 5, 135-139. http://dx.doi.org/10.1007/s12015-009-9059-z

[275] Zhang, Y., Daquinage, A., Traktuev, D.O., et al. (2009) White Adipose Tissue Cells Are Recruited by Experimental Tumors and Promote Cancer Progression in Mouse Models. Cancer Research, 69, 5259-5266. http://dx.doi.org/10.1158/0008-5472.CAN-08-3444 
[276] Gould Halme, D. and Kessler, D.A. (2006) FDA Regulation of Stem-Cell-Based Therapies. The New England Journal of Medicine, 355, 1730-1735. http://dx.doi.org/10.1056/NEJMhpr063086 


\section{Abbreviations}

1) ADD1/SREEP1c: Adipocyte determination and differentiation factor1/sterol regulatory element binding protein-1 (transcription factor to enhance adipogenesis);

2) Activins: Member of the BMP superfamily ligands that may exhibit mixed effects on adipogenesis;

3) BAT: Brown adipose tissue for mainly thermogenesis;

4) BM-MSC: Bone marrow-mesenchymal stem cell;

5) BMP: Bone morphogenetic proteins-Members of the TGF $\beta$ superfamily that may exhibit stimulatory or inhibitory effects on adipogenesis;

6) C/EBP, CCAAT: Enhancer-binding proteins $\alpha, \beta, \delta$-primary transcription drivers of adipocyte gene induction during terminal differentiation;

7) B-catenin: Non-canonical signaling pathway of transnuclear locator;

8) ECM: Extracellular matrix;

9) FABP4: Fatty acid binding protein;

10)GATA2 and GATA3: Inhibit PPAR $\gamma$ activation;

11)HLA DR: Human leukocyte antigen cell marker;

12)LOX: Lysyl cxidase-cytoskeleton associated protein;

13)MMP: Matrix Metalloproteinase: Membrane-bound zinc-peptidases that cleave extracellular matrix components and promotes adipogenesis;

14)MSC: Mesenchymal Stem Cells—multipotential cells that can differentiate into adipocytes, chondrocytes and osteocytes;

15)Myf5: Myogenic transcription signature factor 5;

16)MyoD: Myogenic transcription signature;

17)Myogenin: Myogenic transcription signature;

18)NG2: Mural endothelial cell marker;

19)Nodal: Member of the BMP superfamily ligands that can produce both stimulatory and inhibitory effects on adipogensis;

20)Nocturnin: Cicadian rhythm factor;

21)PPAR $\gamma$ : Peroxisome proliferator-activated receptor gamma—central transcription regulator of differentiation during adipogensis;

22)PDGFR $\beta$ : Mural-endothelial cell marker;

23)Prdm 16: Early marker of brown adipocytes;

24)REV-ER $\beta 2$ : Cicadian rhythm factor;

25)RHO: Family of signaling ligands-receptors that plays a role in inhibiting of stimulating adipogenesis;

26)SM-actin: Mural-endothelial marker;

27)Smad: Cytoplasmic protein receptors that mediate signals to target genes;

28)TAZ: Transcription co-activator;

29)TGF $\beta$ : Transforming growth factor super family ligands that includes the BMP family for crucial for MCS lineage decisions and adipogenic competency of committed preadipocytes;

30)TLE 3: Cicadian rhythm factor;

31)Tpt1: Tumor protein 1that determines the ability of MSCs to commit to adipogenesis through shape regulation;

32)TIMP: Family of MMP tissue inhibitors to terminate differentiation of committed preadipocytes;

33)UCP1: Mitochondrial uncoupler in brown fat cells; 
34)VSC: Vascular stem cells;

35)VE-Cadherin Promotor: Specific marker and requirement for formation of vasculature;

36)WAT: White adipose tissue;

37)WNT: Signaling family of glycoproteins ligands of the canonical or non-canonical pathways that play a key role in stimulation or inhibition of adipogenesis;

38)YAP: Yes-associated protein;

39)Zfp423: Multi-zinc finger transcriptional regulator of preadipocyte commitment. 